Canadian

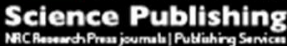

Biochemistry and Cell Biology

Biochimie et biologie cellulaire

\title{
Physico-chemical and In silico analysis of a phytocystatin purified from Brassica juncea cultivar RoAgro 5444
}

\begin{tabular}{|r|l|}
\hline Journal: & Biochemistry and Cell Biology \\
\hline Manuscript ID & bcb-2016-0029.R2 \\
\hline Manuscript Type: & Article \\
\hline Date Submitted by the Author: & $29-$ May-2016 \\
\hline Complete List of Authors: & $\begin{array}{l}\text { Khan, Shumaila; Aligarh Muslim University Faculty of Life Sciences, } \\
\text { Department of Biochemistry } \\
\text { Ahmad, Sabahuddin; Central Drug Research Institute } \\
\text { Siddiqi, Mohammad Imran; Central Drug Research Institute } \\
\text { Bano, Bilqees; Aligarh Muslim University Faculty of Life Sciences, } \\
\text { Department of Biochemistry }\end{array}$ \\
\hline Keyword: & $\begin{array}{l}<\text { i>Brassica juncea</i>, Phytocystatin, Circular dichroism, Isothermal } \\
\text { calorimetry, Protein-Protein Docking }\end{array}$ \\
\hline &
\end{tabular}


1 Physico-chemical and In silico analysis of a phytocystatin purified from Brassica juncea

2 cultivar RoAgro 5444

3 Shumaila Khan ${ }^{1}$, Sabahuddin $\mathrm{Ahmad}^{2}$, Mohammad Imran Siddiqi ${ }^{2}$ and Bilqees Bano ${ }^{1 *}$

$4 \quad{ }^{*}$ Corresponding author

$5{ }^{1}$ Department of Biochemistry, Faculty of Life Science, Aligarh Muslim University, Aligarh 202002, 6 India.

7 Email: bilqeesbano13@gmail.com

8 Telephone no. : +91-9997448621

$9 \quad{ }^{2}$ Molecular and Structural Biology Division, Council of Scientific and Industrial Research-Central 10 Drug Research Institute (CSIR-CDRI), Lucknow 226031, Uttar Pradesh, India. 
1 Abstract

2 This study describes the isolation and purification of a phytocystatin from seeds of Brassica juncea (B.juncea), 3 (cultivar RoAgro 5444), an important oilseed crop with pervasive agricultural and economic ramifications. The 4 protein was purified by gel filtration chromatography with $24.3 \%$ yield and 204 fold purification and visualised 5 by $2 \mathrm{D}$ gel electrophoresis. The $18.1 \mathrm{kDa}$ mustard cystatin was highly specific for cysteine proteinases. The plant 6 cystatin inhibited cathepsin B, confirming its role in conferring pest resistance. The inhibitor was highly stable 7 over a $\mathrm{pH}$ range of 3-10 and retained significant inhibitory potential till $70^{\circ} \mathrm{C}$. The stoichiometry of its 8 interaction with papain, determined by Isothermal Calorimetry suggests a 1:1 complex. Secondary structural 9 elements calculated by far UV circular dichroism (CD) spectroscopy show $18.8 \% \alpha$ helical and $21 \% \beta$ sheet 10 structure. The protein was a non-competitive inhibitor of thiol proteinases. The stoke's radius and frictional co-

11 efficient were used to describe the shape and size of the protein.. Homology modelling and docking studies 12 proposed a prototype illustrating the Brassica phytocystatin mediated papain inhibition. Molecular dynamics 13 (MD) study revealed prominent stability of papain-phytocystatin complex during 100 nanoseconds (ns) long 14 simulation. Detailed results identify the mustard cystatin as an important member of the phytocystatin family.

15 Key words: Brassica juncea, Phytocystatin, Circular dichroism, Isothermal calorimetry, Protein-Protein 16 Docking 


\section{Introduction}

Cystatins comprise a class of cysteine proteinase inhibitors that form equimolar, tight and reversible complexes with the thiol proteinases. Animal cystatins are well characterised and are classified into three main families: Stefins, Cystatins and Kininogens (Abrahamson et al. 2003; Turk et al. 1997). The plant cystatins, commonly called Phytocystatins, form an independent subfamily on the cystatin evolutionary tree (Brown and Dziegielewska 1997) with molecular weight in the range of 8-25kDa (García Olmedo et al. 1987; Ryan 1990). These are basically classified into three groups - Group I: low molecular weight phytocystatins $(\sim 12-16 \mathrm{kDa})$, Group II: $23 \mathrm{kDa}$ phytocystatins that are capable of inhibiting the Legumain (C13) family of proteinases (Lim et al. 1996; Shyu et al. 2004) and Group III: high molecular weight plant cystatins (Walsh and Strickland 1993 ;Wu and Haard 2000). These cysteine proteinase inhibitors are devoid of free thiol groups, disulphide bridges and putative glycosylation sites (Martinez and Diaz 2010). Phytocystatins bear the highly conserved QXVXG sequence, characteristic of the cystatin superfamily. A Proline-Tryptophan dipeptide sequence in the C-terminal region and a conserved Glycine residue in the N-terminal region are also present. A consensus LARFAV-like sequence, present upstream of the reactive QXVXG site is unique to phytocystatins.

Phytocystatins are instrumental in the regulatory and defence response of plants to both biotic and abiotic stimuli. They regulate intracellular protein turnover during seed development and germination (Arai et al. 2002; Corre-Menguy et al. 2002; Martinez et al. 2005) and during programmed cell death (Belenghi et al. 2003; Solomon et al. 1999). A defence role has also been conferred on them due to their ability to inhibit the exogenous cysteine proteinases such as the gut proteinases of invading insects (Haq et al. 2004; Kuroda et al. 1996; Pernas et al. 1998). Enhanced pest resistance has been observed in transgenic plants overexpressing cystatin genes (Álvarez-Alfageme et al. 2007; Gutierrez-Campos et al. 1999; Walker et al. 1999). Phytocystatins are instrumental in inhibition of fungal growth (Martinez et al. 2005). Their expression is induced by wounding and also by exposure to methyl jasmonate, thereby further establishing the role of the inhibitors in defence response (Bolter 1993; Pernas et al. 2000; Zhao et al. 1996).

Rapeseed mustard (Brassica spp.) is the third important oilseed crop grown worldwide with the Indian subcontinent, Central Africa and parts of Russia being the principle growing regions. In India, Brassica spp constitute $28.6 \%$ of the total oilseed production (Shekhawat et al. 2012). Of the various mustard species, oil yielding varieties are Brassica juncea (B. juncea), and Brassica nigra (B.nigra) with Brassica alba (B.alba) being cultivated primarily as a catch crop in India (Panda 2010) and other countries like Poland, Canada etc. 
1 B. juncea commonly known as Indian mustard is the major edible brassica oilseed crop in India and across the 2 world. The crop, however, is highly susceptible to diseases like seedling blight and damping off caused by

3 Rhizoctonia solani, Sclerotium rolfsii and/or Fusarium species. Brassica juncea cultivation is most affected by salinity(Gill et al. 2012)and drought (Zhang et al. 2014). Literature reports that abiotic stress conditions like salinity (Shabala 2009), heavy metal toxicity, temperature extremes (Kratsch and Wise 2000; Tian et al. 2000; Zhang et al. 2014),water stress (Claeys and Inze 2013) and hypoxia (Chang-jie et al. 2004) cause oxidative stress and activation of apoptotic pathways. The mustard plants are also attacked by a number of pests like flea beetles (Phyllotreta species), weevils (Ceutorhyncus assimilis), pollen beetles (Meligethus aeneus) etc. In India, Bagrada hilaris, Pieris brassicae and Lipaphis erysimi (mustard aphid) cause serious damage to the B.juncea crop.

Previously reported studies on phytocystatins provide ample evidence of their inherent anti-fungal activity (Wang et al. 2008) and efficacy in modifying programmed cell death (Santana et al. 2014). Their ability to confer enhanced pest resistance and stability under extreme conditions is also well documented. Indian mustard (B.juncea) is an important crop plant with widespread economic ramifications on the Indian agricultural industry and this knowledge prompted an investigation of its innate cysteine proteinase inhibitor. The present communication provides detailed purification and characterization of a phytocystatin from seeds of B.juncea in terms of its physicochemical properties, kinetic parameters, immunological properties and secondary structural content. The papain-phytocystatin interaction has also been elucidated by molecular docking using a Brassica rapa ssp pekinensis phytocystatin model as a prototype for Brassica phytocystatins. The stability of the complex was evaluated via $100 \mathrm{~ns}$ long MD simulation studies.

\section{Experimental}

\subsection{Materials}

The enzymes (papain, ficin, bromelain, trypsin, chymotrypsin and cathepsin B), substrates (casein, azocasein and p-nitrophenyl phosphate), anti-rabbit IgG and Sephacryl S100-HR were obtained from Sigma Aldrich (St. Louis, MO). Electrophoresis reagents (acrylamide, bisacrylamide, ammonium persulphate) ethylene diammine tetra acetate (EDTA) and L-cysteine were obtained from SRL Pvt. Ltd., India and SERVA Electrophoresis GmbH Medium molecular weight markers, Freund's complete and incomplete adjuvants were obtained from Genei, India Limited. All other chemicals used were of highest purity grade available commercially.

\subsection{Methods}


1

2

3

\subsubsection{Purification of a thiol proteinase inhibitor (TPI) from Indian mustard seeds}

The mustard TPI was purified by modifying the method of Sharma et al. 2006. 100gm of RoAgro 5444 mustard seeds were homogenized in homogenization buffer: $50 \mathrm{mM}$ sodium phosphate buffer, $\mathrm{pH} 7.5$ containing $0.15 \mathrm{M}$ sodium chloride $(\mathrm{NaCl}), 3 \mathrm{mM}$ EDTA and 2\% n-butanol. The crude extract was centrifuged at $8000 \mathrm{rpm}$ for 15 minutes in a REMI cooling centrifuge. Particulate matter was discarded. The supernatant was collected and fractionated by $40-60 \%$ ammonium sulphate saturation. The precipitate collected by centrifugation at 10,000 rpm for 30 minutes at $4^{\circ} \mathrm{C}$ was dissolved in minimum amount of $50 \mathrm{mM}$ sodium phosphate buffer $\mathrm{pH} 7.5$ and dialyzed thrice against the same buffer. The dialyzed sample was chromatographed on the Sephacryl S-100 column $(55 \times 1.9)$, equilibrated with $50 \mathrm{mM}$ sodium phosphate buffer $\mathrm{pH} 7.5$. Fractions of $5 \mathrm{ml}$ were collected and assayed for protein and TPI activity.

\subsubsection{Assay of thiol proteinase inhibitory activity}

The specificity of the purified cystatin towards thiol proteinases was assessed by its ability to inhibit the caseinolytic activity of papain by the method of Kunitz (1947). Aliquots of papain solution $(0.2 \mathrm{mg} / \mathrm{mL})$ were activated with $0.14 \mathrm{M}$ cysteine and $0.047 \mathrm{M}$ EDTA at $37^{\circ} \mathrm{C}$ for 10 minutes in $50 \mathrm{mM}$ sodium phosphate buffer, $\mathrm{pH}$ 7.5. the activated papain was then incubated with $0.2 \mathrm{~mL}$ of the purified inhibitor for 30 minutes at $37^{\circ} \mathrm{C}$. the reaction volume was $1 \mathrm{~mL}$. the reaction was initiated by addition of $1 \mathrm{~mL}$ of $2 \%$ casein solution to the reaction mixture and incubated for 30 minutes at $37^{\circ} \mathrm{C}$. the reaction was stopped by adding $1 \mathrm{~mL}$ of $10 \%$ trichloroacetic acid solution . the particulate matter was removed by centrifugation at $2500 \mathrm{rpm}$ for 10 minutes. Colour was developed in the supernatant by the method of Lowry et al. (1951). A blank was prepared that was devoid of the purified phytocystatin. The inhibitory activity was defined as the decrease in casein hydrolysing activity per $\mathrm{mL}$ of inhibitor solution per minute reaction time. One unit of inhibitor activity of the purified cystatin was defined as the amount of inhibitor bringing about 0.001 change in absorbance per minute per $\mathrm{mL}$.

The ability of the purified inhibitor to inhibit ficin and bromelain was also determined using casein as substrate. Inhibition of cathepsin B by the inhibitor was assayed using the protocol described by Michaud et al. (1993). The protein content of each sample was estimated by the method of Lowry et al. (1951). 
1

2

3

4

5

6

7

8

\subsubsection{Electrophoresis}

The homogeneity of the purified protein preparation was checked by $2 \mathrm{D}$ gel electrophoresis. $200 \mu \mathrm{g}$ of the chromatographed protein was focused on IPG strips, pI 3-10, according to the protocol of Khan et al. (2014), using a IEF100 First-dimension Isoelectric Focusing Unit, Hoefer, Inc. USA. After focussing, the IPG strip was subjected to the same treatment as that described by the aforementioned group. The IPG strip was then placed on a $12.5 \%$ SDS-polyacrylamide gel and electrophoresis was performed at a constant voltage of $100 \mathrm{~V}$. The gels were stained with a $0.1 \%$ Coomassie brilliant blue R-250 preparation for 1 hour. Destaining was performed using a methanol (20\%), glacial acetic acid (10\%) and distilled water solution.

To determine the molecular mass of the purified TPI, the samples were electrophoresed on $12.5 \%$ SDS polyacrylamide gels in the presence and absence of reducing agent, $\beta$ mercapto ethanol (Laemmli 1970). The molecular weight of the mustard cystatin in the native state was also determined by passing several marker proteins along with the inhibitor on Sephacryl S100-HR column.

\subsubsection{Thiol group estimation}

The presence of thiol groups in the purified mustard cystatin was determined by the method of Ellman (1959). L-cysteine was used to prepare the standard plot.

\subsubsection{Carbohydrate estimation}

The carbohydrate content of the purified protein was measured by the method of Dubois et al. (1956) where DGlucose was used as standard.

\subsubsection{Thermal stability of the inhibitor}

a. $50 \mu \mathrm{g}$ of the inhibitor was incubated in $50 \mathrm{mM}$ sodium phosphate buffer $(\mathrm{pH} 7.5)$ at various temperatures ranging from $30^{\circ} \mathrm{C}-90^{\circ} \mathrm{C}$ for 30 minutes. The samples were rapidly cooled and the

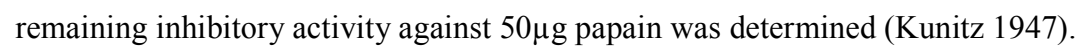


b. The purified inhibitor was incubated at $80^{\circ} \mathrm{C} .50 \mu \mathrm{g}$ aliquots of the protein were drawn from the incubated protein at different time intervals of 30,60, 90 and 120 minutes and assayed for thiol proteinase inhibitory activity.

c. The purified inhibitor was stored at $-20^{\circ} \mathrm{C}$ and $4^{\circ} \mathrm{C} .50 \mu \mathrm{g}$ aliquots of the protein were drawn at intervals of 7, 14, 30, 45, 60 and 90 days and assayed for papain inhibition.

\subsection{7. pH stability of the inhibitor}

$50 \mu \mathrm{g}$ of the inhibitor was incubated with buffers of different $\mathrm{pH}$ in the range of 3-12: $50 \mathrm{mM}$ sodium acetate buffer (pH 3.0, 4.0 and 5.0) 50mM sodium phosphate buffers (pH 6.0, 7.0 and 8.0), 50mM Tris- $\mathrm{HCl}$ buffer (pH 9.0 and 10.0) and 50mM NaOH-Glycine buffer (pH 11.0 and 12.0) for 30 minutes. The potency of papain inhibition by the treated mustard cystatin was determined by the procedure reported by Kunitz (1947).

\subsubsection{Hydrodynamic Properties}

The stokes radius (r) of the purified inhibitor was determined by running the inhibitor on a Sephacryl S100-HR column, calibrated with proteins of known stokes radii (Andrews 1964; Laurent and Killander 1964). The frictional co-efficient (f) and diffusion constant (D) were then calculated (Erickson 2009).

\subsubsection{Immunological Properties}

The immunological purity of the purified protein was determined by raising antisera in male albino rabbits in response to subcutaneous injections of $300 \mu \mathrm{g}$ inhibitor emulsified in Freund's complete adjuvant. Following this injection, the purified cystatin was administered weekly in Freund's incomplete adjuvant. The rabbit was bled every 14 days. The collected blood was allowed to stand and coagulate at room temperature for $3 \mathrm{hr}$. Decomplementation of the anti-sera was performed by incubation at $56^{\circ} \mathrm{C}$ for 30 minutes. The de-complemented sera was then stored at $-20^{\circ} \mathrm{C}$. Immuno-diffusion was performed according to the protocol described by Ouchterlony and Nillson (1978).

Direct binding ELISA was performed to measure the antigen specific antibodies generated in mustard TPI immunized rabbits (Voller et al. 1976). 
1

2

3

4

5

6

\subsubsection{Kinetic Analysis}

\section{Stoichiometry of papain inhibition by mustard TPI}

The stoichiometry of papain inhibition by mustard cystatin was determined by Isothermal Calorimetry (ITC) using MicroCal VP-ITC (Malvern Instruments). Both papain and mustard cystatin solutions were prepared in $50 \mathrm{mM}$ sodium phosphate buffer ( $\mathrm{pH} 7.5)$. Prior to experiment, the papain $(100 \mu \mathrm{M})$, cystatin $(10 \mu \mathrm{M})$ and buffer solutions were filtered and then degassed for 10 minutes at $37^{\circ} \mathrm{C}$ using the Microcal Thermovac attachment of the instrument. The reference and sample cells were filled with the buffer and inhibitor solutions respectively. The protein solution in the sample cell was stirred at $309 \mathrm{rpm}$ and titrated with 29 consecutive $10 \mu \mathrm{L}$ injections of papain. Control experiments involved titration of papain with buffer alone and the integrated data was subtracted from the data obtained from the papain-cystatin titration to eliminate the heat of dilution. The integrated heat data of the titration were then analysed by the MicroCal analyser.

\section{$K_{\mathrm{i}}$ determination}

Varying concentrations of the purified TPI $(0.6 \mu \mathrm{M}-0.30 \mu \mathrm{M})$ were made to react with papain, ficin and bromelain fixed at $0.6 \mu \mathrm{M}$. Residual activity was measured using casein as substrate (Kunitz 1947). Four different substrate concentrations were used: $0.5 \mathrm{~K}_{\mathrm{m}}, 1 \mathrm{~K}_{\mathrm{m}}, 2 \mathrm{~K}_{\mathrm{m}}$ and $3 \mathrm{~K}_{\mathrm{m}}$. The results were analysed by constructing double reciprocal plots (Dixon and Webb 1979).

\section{Determination of dissociation rate constant $\left(\mathbf{K}_{-1}\right)$}

Maximal association between the purified inhibitor and enzyme was achieved by incubating the TPI and enzyme at $37^{\circ} \mathrm{C}$ for 30 minutes. The reaction was then shifted towards dissociation by adding excess substrate $(6 \%$ casein) which also binds the free enzyme. The substrate was allowed to interact with the TPI-enzyme complex for different time periods before the reaction was stopped by the addition of TCA and the enzyme activity was then determined.

The association rate constant $\left(\mathrm{K}_{+1}\right)$ was determined using the equation (Abrahamson et al. 1986)

$$
\mathbf{K}_{+1}=\mathbf{K}_{-1} / \mathbf{K}_{\mathbf{i}}
$$

The half-life $\left(\mathrm{t}_{1 / 2}\right)$ of the inhibitor-enzyme complex and the dissociation rate constant are related by the equation

$$
t_{1 / 2}=0.693 / K_{-1}
$$


1

2

3

4

5

6

7

8

9

10

\subsubsection{Spectral analysis}

Ultra violet spectrum of purified mustard TPI $(2 \mu \mathrm{M})$ was measured on UV mini spectrophotometer. The wavelength range was $190-300 \mathrm{~nm}$ and path length was $1.0 \mathrm{~cm}$. Each spectrum was the average of three scans.

Far UV (190-240nm) CD spectrum of the purified inhibitor were recorded on a JascoJ-815 spectropolarimeter at room temperature using $1 \mathrm{~nm}$ bandwidth, $100 \mathrm{~nm} \mathrm{~min}^{-1}$ scanning speed and $1 \mathrm{~mm}$ slit width. The protein concentration was $0.2 \mathrm{mg} / \mathrm{mL}$ and the ellepticity values were expressed in millidegrees. The fractional percentages of the secondary structure of the protein were calculated by the online server, BestSel (Micsonai et al. 2015).

\subsubsection{Homology Modeling}

A 101 amino acid long phytocystatin sequence of Brassica rapa ssp pekinensis was retrieved from the universal protein resource (UniProt) database (ID: Q71QE1) in FASTA format (UniProt 2015). The protein-protein BLAST (blastp) program (Altschul et al. 1990) was used against Protein Data Bank to identify the homologues sequences with their structures. The top hit was considered as a template to construct the desired three dimensional (3D) model of phytocystatin. This template was also subjected to Clustal Omega (V.1.2.1) (Sievers et al. 2011)for multiple sequence alignment to identify the conserved residues in the phytocystatin sequence and the template. The 3D model of phytocystatin was constructed using the automodel routine of Modeller (V.9.12) (Šali and Blundell 1993). 100 theoretical model were constructed which needed further evaluation to select the best one for future experiments in this study. Starting with the inbuilt routine of Modeller called DOPE score, top 10 models were selected. These models were subjected to various evaluation programs like PROCHECK (Laskowski et al. 1993), ProQ (Wallner and Elofsson 2003) and QMEAN (Benkert et al. 2009).

\subsubsection{Docking studies}

Docking of modelled phytocystatin with papain was performed using the docking program ZDOCK (Chen et al. 2003) included in Discovery Studio which is a software suite developed and distributed by Accelrys. ZDOCK is rigid-body docking program and requires minimal information about the binding site. Crystal structure coordinates of papain (PDB code: 3E1Z, chain B) from the plant, Carica papaya was obtained from Protein 
1 Data Bank. It is a complex of parasite protease inhibitor, chagasin (chain A) and papain (Redzynia et al. 2009).

2 From this protein structure, chain A and all hetero atoms including water were removed. The resulting structure

3 was subjected to protein preparation protocol 'Prepare Protein' of Discovery Studio. Default parameters were

4

\subsubsection{Molecular Dynamics (MD) simulations}

To evaluate the stability of the papain and phytocystatin complex, MD studies were performed. GROningen MAchine for Chemical Simulations (GROMACS) v5.0.7 package (Abraham et al., 2015) was considered for this study. Protein topology was prepared considering 'GROMOS96 43a1' force field (Scott et al., 1999) using the module 'gmx pdb2gmx' of GROMACS. The solvated system had a net charge of +2.0 . Therefore, 2 Chloride ions were added to neutralize the system. The system was then minimized using the steepest descent method. Minimized system was subjected to equilibration run in two consecutive steps, NVT (Number of particles, Volume and Temperature) equilibration run and NPT (Number of particles, Pressure and Temperature) equilibration run. Equilibrated system was subjected to a $100 \mathrm{~ns}$ long MD run at $300 \mathrm{~K}$ to confirm stability of the given system. The hydrogen bonds between papain-phytocystatin and the root mean square deviation (RMSD) of the proteins, its complex were calculated using the module 'gmx hbond' and 'gmx rms' modules of GROMACS respectively. Similarly, 'gmx energy' was considered to elucidate the interaction energy pattern during 100 ns MD simulation.

\section{Statistical Analyses}

Each experiment was performed three times to check the reproducibility of the results. The data was expressed as the Mean \pm standard error mean (SEM) for three independent experiments. The statistical significance was evaluated by one-way ANOVA software. The probability of occurrence was determined at $\mathrm{p} \leq 0.05$. 
1

2

3

4

5

6

7

8

9

10

11

12

13

\section{Results}

\subsection{Purification of the inhibitor}

In the present work, the TPI purification procedure involved two steps after homogenization: ammonium sulphate precipitation (40-60\%) and gel filtration chromatography on Sephacryl S-100 HR column. Table 1 summarises the progress of purification. The inhibitor eluted as a single peak giving significant papain inhibition (figure 1). The fractions corresponding to the peak were pooled and used for further analysis. The inhibitor was purified with a fold purification of 204 and a per cent yield of 24.3.

\subsection{Homogeneity of the purified mustard TPI}

The inhibitor eluted as a single symmetric peak with significant papain inhibitory activity (figure 1). Moreover, the purity and homogeneity of the preparation was envisioned by 2D gel electrophoresis (figure 2).

\subsection{Properties of the purified TPI}

\subsubsection{Molecular weight determination}

A single band was obtained in SDS-PAGE under both reducing and non-reducing conditions indicating that the purified inhibitor is a monomeric protein with no sub-units (figure 3). The molecular weight of the purified TPI as determined by gel filtration on Sephacryl S100-HR column was $18.6 \mathrm{kDa}$. It was further confirmed by SDSPAGE under reducing and non-reducing conditions. The molecular weight obtained under reducing conditions was $18.3 \mathrm{kDa}$ while that under non-reducing conditions was $18.1 \mathrm{kDa}$.

\subsubsection{Sulfhydryl group estimation}

Neither free thiol groups nor disulphide linkages were observed in the purified mustard cystatin.

\subsubsection{Carbohydrate group estimation}

The TPI was devoid of carbohydrate groups as estimated spectrophotometrically. 
1

2

3

4

5

6

7

8

\subsubsection{Stability Studies}

\section{Temperature profile}

The purified TPI was found to be quite stable and active in the temperature range of $30-60^{\circ} \mathrm{C}$ (figure $4 \mathrm{a}$ ). It retained about $75 \%$ of its anti-papain activity at $70^{\circ} \mathrm{C}$. A progressive decrease in its inhibitory activity was noted beyond $60^{\circ} \mathrm{C}$, with significant loss of activity at $90^{\circ} \mathrm{C}$. When incubated at $90^{\circ} \mathrm{C}$, the purified protein retained $40 \%$ of its anti-papain activity till 90 minutes (figure $4 \mathrm{~b}$ ). The inhibitor also retained $60 \%$ of its inhibitory potential for upto 120 days at $-20^{\circ} \mathrm{C}$ and $55 \%$ of its inhibitory potential for upto 45 days at $4^{\circ} \mathrm{C}$ (data not shown).

\section{pH stability profile}

Stability of the purified TPI was investigated as a function of $\mathrm{pH}$ between $\mathrm{pH}$ 3-12. Figure 5 shows that the inhibitor is stable in the $\mathrm{pH}$ range of 3.0-9.0 and exhibits maximal activity at $\mathrm{pH}$ 7.5.Above $\mathrm{pH} 9.0$, the TPI retained minimal anti-papain activity with complete loss of activity at pH 12.0.

\subsubsection{Hydrodynamic properties}

Hydrodynamic parameters as determined by the gel filtration behaviour of the purified inhibitor suggested a stokes radius of $2.07 \mathrm{~nm}$. Using the Stokes radius, the frictional coefficient was calculated to be $3.903 \times 10^{-8} \mathrm{~g} / \mathrm{s}$. The Diffusion co-efficient was found to be $1.05 \times 10^{-10} \mathrm{~m}^{2} / \mathrm{s}$.

\subsubsection{Immunological properties}

Immunodiffusion results proved the immunogenic purity of the inhibitor as a single precipitin line was observed (supplementary data figure 1). Direct binding ELISA gave a titer value of 23442.29 hinting at a high antigenicity of the protein (supplementary data figure 2).

\subsubsection{Kinetic properties}

The energetics of the papain-mustard cystatin interaction were monitored by ITC. Figure 6 represents the isotherm for the reaction. These calorimetric titrations yield a stoichiometry of $\sim 1( \pm 0.0306)$ indicating that a 
1 specific 1:1 complex is formed. The mustard cystatin exhibited significant affinity for papain with a binding 2 constant $(\mathrm{K})$ value of $1.2 \times 10^{6} \pm 4.23 \times 10^{4} \mathrm{M}^{-1}$.

3 The dissociation equilibrium constant (measured as $\mathrm{K}_{\mathrm{i}}$ ), the dissociation rate constant, the association rate 4 constant and the half-life of the inhibitor-enzyme complex for papain, ficin and bromelain have been mentioned

5 in Table 2. The $\mathrm{K}_{\mathrm{i}}$ values obtained for papain, ficin and bromelain are $0.102,0.306,0.468 \mu \mathrm{M}$ respectively, 6 implying the highest affinity of inhibitor for papain. The $\mathrm{K}_{-1}$ values for the enzyme-inhibitor complex were determined by the displacement procedure, in which the inhibitor released from the complex with increase in time was trapped by excess substrate. The $\mathrm{K}_{-1}$ values obtained for papain, ficin and bromelain are $6.6 \times 10^{-4}$, $9.23 \times 10^{-4}, 10.25 \times 10^{-4} \mathrm{~s}^{-1}$ respectively. Association rate constant and hence the affinity of the inhibitor for proteinases is in the following order: papain $\left(6.47 \times 10^{3} \mathrm{M}^{-1} \mathrm{~s}^{-1}\right)>$ ficin $\left(3.01 \times 10^{3} \mathrm{M}^{-1} \mathrm{~s}^{-1}\right)>$ bromelain $\left(2.19 \times 10^{3}\right.$ $\left.\mathrm{M}^{-1} \mathrm{~s}^{-1}\right)$. The half-life of the enzyme inhibitor complex calculated with papain was observed to be $1.05 \times 10^{3} \mathrm{~s}$ while with ficin it was $0.75 \times 10^{3} \mathrm{~s}$ and for bromelain, the half-life was calculated to be $0.67 \times 10^{3} \mathrm{~s}$.

\subsubsection{Spectral studies}

The purified mustard cystatin yields typical UV absorption spectra with a maximum at $279 \mathrm{~nm}$ and a minimum at $253 \mathrm{~nm}$. The molar extinction co-efficient calculated for the protein at $280 \mathrm{~nm}$ was $13,233.3 \mathrm{M}^{-1} \mathrm{~cm}^{-1}$ while the 280/260 absorbance ratio is 1.3 . The secondary structural contents of the inhibitor were determined from the far UV CD data (figure 7). The $\alpha$ helical, $\beta$ sheet and $\beta$ turn content of the protein, determined by the BestSel server was $18.8 \%, 21 \%$ and $15 \%$ respectively.

\subsection{In silico analysis}

The protein-protein BLAST resulted into eight hits from protein data bank. The top hit, 3IMA was considered as a template model. 3IMA shows $90 \%$ query coverage and $59 \%$ sequence identity with the phytocystatin sequence. The template model, 3IMA has four chains. Only chain B and D constitutes the tarocystatin from the plant Colocasia esculenta (taro). The chain D of 3IMA was considered for modelling the structure of queried phytocystatin. Multiple sequence alignment of 3IMA using Clustal Omega with the query sequence revealed the conservation of several regions in both the proteins (figure 8). 
1 The 3D models constructed though modeller were subjected to several programs for evaluation. Top ten models 2 on the basis of DOPE score, were picked from all the 100 models constructed. Theoretical Model 07(figure 9), 3 was found to be the best model among ten shortlisted. Complete evaluation details of the top ten models are summarised (Table 3). According to PROCHECK evaluation of Model 07, 92.3\% residues of this model fall in

5 the most favoured region, 7.7\% residues fall in the additionally allowed region. And none residues were found in the generously allowed and disallowed region (figure 10). QMEAN (Z-score) is a comparison with nonredundant set of PDB structures. The score for this evaluation comes out to be -0.43 (figure 11). Protein quality estimation was also performed using ProQ web server, which evaluates the model on the basis of LG score and MaxSub score. LG score and MaxSub score of Model 07 were found to be 2.096 and 0.307 respectively. LG score $>1.5$ and MaxSub score $>0.1$ corresponds to correct model.

Molecular visualisation of phytocystatin model provided secondary structure information, which illustrated six beta sheets and one alpha helix. From the docking conformations, all 2000 poses were browsed. This enabled the listing of all 2000 poses on the basis of Z Rank score. Best docked conformation (pose 1 from cluster 13) had Z-Rank Score: -111.95 (Z Dock Score: 17.16). This conformation (figure 12) was saved and visualised in detail for possible interactions in between the two proteins. As evident from the image (figure 13), modelled phytocystatin interacts with papain via seven hydrogen bonds. Details of the hydrogen bond interactions are summarised in Table 4.

MD study revealed detailed information of the papain-phytocystatin interaction and its stability. Higher number of hydrogen bond formation represents higher number of protein to protein/ligand interactions and hence higher stability. On an average, 13.242 hydrogen bonds were formed between the two proteins during $100 \mathrm{~ns}$ long simulation. In final stages of simulation (i.e. from $65 \mathrm{~ns}$ onwards), $>20$ hydrogen bonds were also seen at some instance (figure 14). Protein complex was saved at $20 \mathrm{~ns}, 40 \mathrm{~ns}, 60 \mathrm{~ns}, 80 \mathrm{~ns}$ and $100 \mathrm{~ns}$ for detailed analysis of residue pairs involved in formation of papain-phytocystatin complex. Corresponding changes were noticed in the interaction energy pattern evolved due to protein-protein interaction (figure 15). Energy was found least for all the instances where hydrogen bond were maximum and vice versa. Falling energy levels clearly indicates the increased stability of the complex with the passage of time. Table 5 lists the residue pairs involved in the formation of hydrogen bonds during the MD simulation. RMSD of the proteins from their initial structure was also evaluated. Proteins were found coming to stabilized state by the end of simulation on the basis of the 
1

2

complex. The possible reason for this drastic variation in RMSD could be the homology modelled structure of phytocystatin. Phytocystatin alone had more structural variation from 40 ns onwards. However, the RMSD of the papain-phytocystatin complex is found stabilized by the end of simulation supporting that papain and the phytocystatin have adapted themselves in due course and bind strongly with each other.

\section{Discussion}

Phytocystatins have important regulatory roles in plant physiology owing to their cysteine proteinase inhibitory activity. Several other roles have been attributed to cystatins in plants: from the control of various physiological and cellular processes in plants (organogenesis, seed development, programmed cell death and storage protein turnover) to the inhibition of exogenous cysteine proteases secreted by herbivorous arthropods and pathogens to digest or colonize plant tissues. The isolation of a thiol proteinase inhibitor from oil yielding mustard seeds had not been previously attempted. Thus, it was envisaged that a systematic study of a thiol proteinase inhibitor from the new source i.e. Brassica juncea will be useful in adding to the existing data and knowledge on phytocystatins.

The present report describes the purification and characterization of a thiol proteinase inhibitor from IndiAN mustard which was found to be highly specific for cysteine proteinases namely papain, ficin, bromelain and cathepsin B. Amongst these, the TPI was found to be maximally effective towards papain followed by cathepsin B, ficin and then bromelain. Practically no inhibitory action was observed against serine (trypsin and chymotrypsin) proteinases (supplementary data figure 4). The ability of the purified protein to inhibit cathepsin B makes it a key player in conferring resistance against pests and predators. Phytocystatins inhibiting animal cathepsins have been reported in strawberry (Martinez et al. 2005), rice (Ohtsubo et al. 2005) and kiwifruit (Rassam and Laing 2004).A simple two step purification procedure involving 40-60\% ammonium sulphate fractionation and gel filtration on Sephacryl S100-HR column provided a 204 fold purification and a 24.3 per cent yield. The purified TPI, when passed through a Sephacryl S100-HR column indicated a molecular mass of $18.6 \mathrm{kDa}$. This was further corroborated by electrophoresis wherein the molecular mass was calculated to be 18.1kDa. A $26 \mathrm{kDa}$ phytocystatin has been observed in yellow mustard seeds (Brassica alba) while a $23 \mathrm{kDa}$ protein was reported in B.rapa flower buds (Hong et al. 2008). The inhibitor migrated as a single band on SDSPAGE indicating the single subunit structure of the protein and absence of disulphide bonds. The TPI was found to be devoid of thiol groups and carbohydrate moieties. These physical properties of the purified inhibitor 
1 are consistent with the intrinsic properties that identify a protein as a group II Phytocystatin (Benchabane et al.

2 2010).

3 Most of the purified phytocystatins are stable to extremes of temperature and $\mathrm{pH}$ (Pernas et al. 1998). The 4 ability of the purified B.juncea seed cystatin to remain stable over a wide $\mathrm{pH}$ range of 3-9 and temperature range 5 of $30-60^{\circ} \mathrm{C}$ holds it in good stead as compared to other Brassica phytocystatins like yellow mustard (B.alba) cystatin (Ahmed et al., 2016) and chinese cabbage (B.rapa) cystatin (Hong et al., 2012) that show stability in the

$7 \mathrm{pH}$ ranges of 6-8 and up to $\mathrm{pH} 7$ respectively. The storage stability of the Indian mustard cystatin shows that it is viable up to 4 months when stored at $-20^{\circ} \mathrm{C}$ and 45 days when stored at $4^{\circ} \mathrm{C}$. Storage stability of up to 4 months 9 has been reported for goat pancreas cystatin when stored at $0^{\circ} \mathrm{C}$ (Priyadarshini and Bano, 2005).

10 An investigation of the hydrodynamic parameters revealed a stokes radius of $2.07 \mathrm{~nm}$ and a frictional co11 efficient of $3.903 \times 10^{-8} \mathrm{~g} / \mathrm{s}$. This is in accordance with the hydrodynamic parameters reported for Phaseolus 12 mungo cystatin II wherein the reported stokes radius was 2.05nm (Sharma et al. 2006). A comparison of the 13 frictional co-efficient (f) with the minimal frictional co-efficient $\left(f_{\text {min }}\right)$ which is the frictional co-efficient 14 obtained if the protein was a smooth sphere of radius $r_{\min }$ without the bound water molecules suggests the shape of the protein. In our case, this comparison suggests a slight deviation from the globular structure of the purified protein. The purified cystatin invokes a good immune response as is evident from the antibody titer value obtained. A similar value has been reported for $\alpha$ glycinin and other soy proteins that function as potent allergens (Lalles et al. 1995). Interestingly, a titer value of 22000 was observed for B.alba cystatin that has a molecular weight of $26 \mathrm{kDa}$ while the $\sim 18 \mathrm{kDa}$ B.juncea cystatin mounted an immune response with an antibody titer value of 23442.29, suggesting higher antigenicity of the B.juncea cystatin.

A 280/260 absorbance ratio of 1.3 hints at a sufficiently pure protein preparation devoid of any significant nucleic acid contamination (Zabriskie and DiPaolo 1988). The secondary structure of the purified inhibitor was elucidated by the far UV CD spectrum which shows negative peaks at 208 and $223 \mathrm{~nm}$, corresponding to the alpha-helix conformational elements. Beta sheet shows a negative band at $218 \mathrm{~nm}$ and a positive one at $196 \mathrm{~nm}$. The $\alpha$-helical content of the inhibitor calculated using the BestSel online program is $18.8 \%$ while the $\beta$ sheet and $\beta$ turn conformations are $21 \%$ and $15 \%$ respectively. Reports have shown comparable secondary structural contents for phytocystatins from pineapple (Irene et al., 2012), yellow mustard (Ahmed et al. 2016), Phaseolus mungo (Sharma et al. 2006). The calculated secondary structure for mustard cystatin is similar to animal 
1 cystatins like goat pancreatic (17\%) and human placental (21\%) cystatins previously described in our lab

2 (Priyadarshini and Bano 2010; Rashid et al. 2006).

3 Titrations of papain with mustard cystatin consistently indicate that one mole of papain is inhibited by one mole

4 of the purified TPI suggesting that one papain binding site is present per mustard cystatin polypeptide.

5 Stoichiometric ratios other than 1:1 have also been reported. An inhibitor-papain binding ratio of 1:1.1 was observed in Clitocypin (Brzin et al. 2000), 1:2 for a synthetic peptide (Björck et al. 1989) and 1:8 in tomato (Wu and Haard 2000). The papain-mustard cystatin interaction is highly endothermic and the purified inhibitor showed significant affinity towards papain as is evident by its $\mathrm{K}$ value. These binding affinity values are comparable to those determined by ITC experiments for the potato multicystatin $5\left(\mathrm{~K}_{\mathrm{d}}=7.2 \mu \mathrm{M}\right)(\mathrm{Green}$ et al. 2013).

The purified protein is a potent inhibitor of thiol proteinases. Of the plant cysteine proteinases studied, the mustard TPI binds most tightly to papain, followed by ficin and then bromelain (supplementary data figure 4). The ability of the plant cystatin to inhibit an animal cysteine proteinase like cathepsin B makes it a key player in conferring resistance against predators and insects. The $\mathrm{K}_{\mathrm{i}}$ value towards papain is $1.02 \times 10^{-7} \mathrm{M}$ are comparable to those reported in yellow mustard $\left(\mathrm{K}_{\mathrm{i}}: 3 \times 10^{-7} \mathrm{M}\right)$, the dimeric form of chinese cabbage $\left(\mathrm{K}_{\mathrm{i}}: 1.01 \times 10^{-7} \mathrm{M}\right)(\mathrm{Hong}$ et al. 2012) and soya $\left(\mathrm{K}_{\mathrm{i}}: 1.9 \times 10^{-7} \mathrm{M}\right)$ but are one order of magnitude lower than the values for strawberry (Martinez et al. 2005), barley (Martinez et al. 2003) and sesame (Shyu et al. 2004). Amongst the mustard cystatins, the B.juncea cystatin is a more potent inhibitor than B.alba (yellow mustard) cystatins. The $\mathrm{K}_{\mathrm{i}}$ values obtained are in good comparison with thiol proteinase inhibitors from both the plant (Sharma et al. 2006) and the mammalian system (Rashid et al. 2006; Sumbul and Bano 2006). Tight binding inhibitors have high association rate constants. Among the thiol proteinases studied, papain has the highest $\mathrm{K}_{+1}$. The weaker binding of mustard TPI to bromelain is largely due to a low dissociation rate constant, $\mathrm{K}_{-1}$. The Line-weaver Burk plots for the mustard TPI-enzyme interactions suggest a non-competitive mode of inhibition (supplementary data figure 5). Non-competitive mode of inhibition by phytocystatins has previously been reported in soyabean cystatins (Zhao et al. 1996). Additionally, the non-competitive inhibition of cysteine proteinases by phytocystatins is further supported by the docking model of cysteine proteinase inhibitor interaction with cysteine proteinases proposed from crystallographic data (Bode et al. 1988; Stubbs et al. 1990). The $t_{1 / 2}$ values for the enzyme inhibitor complex for papain, ficin and bromelain are $1.05 \times 10^{3}, 7.5 \times 10^{2} 6.7 \times 10^{2} \mathrm{~s}$ 
1 binary complexes. Similar trends have been observed for the goat pancreas and lung cystatins (Khan and Bano

2 2009; Priyadarshini and Bano 2010).

3 Papain is a prominent member of the cysteine proteinase family. The specificity and potency of papain 4 inhibition by mustard cystatin prompted the investigation of its papain inhibitory nature at an atomic level. In 5 lieu of the availability of the amino acid sequence of the phytocystatins purified from $B . j u n c e a$, the available 6 phytocystatin sequence from B.rapa ssp pekinensis (UniProt ID: Q71QE1) was used as a Brassica cystatin 7 prototype. A pairwise sequence alignment between phytocystatins from B.rapa ssp pekinensis (UniProt ID: 8 Q71QE1) and B.campestris (Q39270) using the EMBOSS Water tool gave 64\% identity and 79\% similarity. 9 Values of $33 \%$ identity and 51\% similarity were observed for an alignment between B.rapa ssp pekinensis 10 (UniProt ID: Q71QE1) and B. oleracea (UniProt ID: Q2A9P9) cystatins. Based on these alignments, it was safe 11 to assume that the purified mustard cystatin will show comparable sequence homology with the above 12 mentioned members of the Brassica family and the docked papain-B.rapa ssp pekinensis cystatin model may 13 serve as an archetype and provide vital information of the papain-B.juncea inhibitor interaction.

14 Papain has four active site residues (Redzynia et al. 2009) namely, Gln19, Cys25, His159 and Asn175.The Gln19 residue of papain has been implicated in catalysis since it stabilises the tetrahedral catalytic intermediate by forming an oxyanion hole (Menard et al. 1991). After inspecting the interactions of the docked complex, it was evident that the Val56 of the modelled phytocystatin binds with the papain's active site residue Gln19 which may check the proteinase activity of the protein. This interaction was also viable during the last phases of the simulation (Table 5). At $80 \mathrm{~ns}$, the Val56 of cystatin was found interacting with papain's Gln19, but Val57 takes the place of Val56 at 100 ns. Moreover, several other important interactions leading to hydrogen bond formation were also discernible from visual inspection of docked complex. Gly11 of modelled phytocystatin was found interacting with Asp158 of papain. This interaction remained persistent throughout the $100 \mathrm{~ns}$ simulation. The docking study was validated with the help of known complex structure of tarocystatin with papain (PDB id: 3IMA) (Chu et al. 2011). The hydrogen bond interactions of this complex reveal similar interactions between the conserved Gly5 of tarocystatin and Asp158 of papain (Chu et al. 2011). This interaction is also found to be conserved in the papain-pineapple cystatin complex (Irene et al. 2012). Modelled phytocystatin have also been found interacting with the Gly20, Gly66 of papain similar to tarocystatin-papain complex (3IMA) (supplementary data Table 1). Additionally, some interactions of phytocystatin were found 
1 2015). The residues lining the $S_{2}$ pocket of papain are (Redzynia et al. 2009) Tyr67, Pro68, Val133, Val157, $2 \quad$ Ala160 and Ser205.

3 Based on the docking cum MD simulation studies, we propose that conserved residues Val56 or Val57 (of the 4 QVVAG sequence) of the modelled cystatin makes the first point of contact with Gln19 of papain. Gly11 of the

5 N-terminal conserved region then interacts with Asp158 of papain in the catalytic cleft. The complex formed is 6 stabilised by interactions between the residues preceding the conserved glycine residue, like Leu10 and the $\mathrm{S}_{2}$

7 subsite (Machleidt et al. 1989). Since all residues involved in the inhibition are conserved across cystatins, it 8 would be prudent to say that B.juncea cystatin's mechanism of papain inhibition would be the same. This report 9 provides the first elucidation of the papain-Brassica phytocystatin interaction mechanism

10 On the basis of its physical and chemical properties, the B.juncea seed cystatin is a good cohort of other seed 11 phytocystatins. Its ability to withstand a wide range of temperature and $\mathrm{pH}$ and successfully inhibit both plant 12 and animal cysteine proteinases (cathepsin B), holds it in good stead as a putative target for genetically modifying the expression and activity of endogenous proteinase inhibitors. These genetically modified plants may be better equipped to overcome both biotic and abiotic stress conditions, thereby increasing the gross productivity of the plant and consequent yield of mustard oil.

\section{Acknowledgements}

The financial assistance provided under the DBT-BUILDER program (No. BT/PR4872/INF/22/150/2012) and the facilities provided by the Department of Biochemistry, Aligarh Muslim University, Aligarh and the Molecular and Structural Biology Division, Council of Scientific and Industrial Research-Central Drug Research Institute (CSIR-CDRI), Lucknow are gratefully acknowledged. The authors wish to thank Dr.Medha Priyadarshini and Ms. Sarah Iqbal for their valuable advice. 


\section{References}

2 Abraham, M.J., Murtola, T., Schulz, R., Páll, S., Smith, J.C., Hess, B. and Lindahl, E. 2015. GROMACS: High

3 performance molecular simulations through multi-level parallelism from laptops to super computers. SoftwareX.

4 1-2: 19-25.

5 Abrahamson, M., Alvarez-Fernandez, M., and Nathanson, C.M. 2003. Cystatins. Biochemical Society $6 \operatorname{symposium(70):179-199.~}$

7 Abrahamson, M., Barrett, A.J., and Salvesen, G. 1986. Isolation of six cysteine proteinase inhibitors from

8 human urine. Their physicochemical and enzyme kinetic properties and concentrations in biological fluids. J

9 Biol Chem. 261(24): 11282-11289.

10 Ahmed, A., Shamsi, A., and Bano, B. 2016. Purification and biochemical characterization of phytocystatin from 11 Brassica alba. J Mol Recognit. 29(5):223-31.

12 Altschul, S.F., Gish, W., Miller, W., Myers, E.W., and Lipman, D.J. 1990. Basic local alignment search tool. J 13 Mol Biol. 215(3): 403-410.

14 Álvarez-Alfageme, F., Martínez, M., Pascual-Ruiz, S., Castañera, P., Diaz, I., and Ortego, F. 2007. Effects of potato plants expressing a barley cystatin on the predatory bug Podisus maculiventris via herbivorous prey feeding on the plant. Transgenic Res. 16(1): 1-13.

Andrews, P. 1964. Estimation of the molecular weights of proteins by Sephadex gel-filtration. Biochem J. 91(2): $222-233$

Arai, S., Matsumoto, I., Emori, Y., and Abe, K. 2002. Plant seed cystatins and their target enzymes of endogenous and exogenous origin. J Agric Food chem. 50(22): 6612-6617.

21 Belenghi, B., Acconcia, F., Trovato, M., Perazzolli, M., Bocedi, A., Polticelli, F., Ascenzi, P., and Delledonne, M. 2003. AtCYS1, a cystatin from Arabidopsis thaliana, suppresses hypersensitive cell death. Eur J Biochem. 270(12): 2593-2604.

Benchabane, M., Schlüter, U., Vorster, J., Goulet, M.,C., and Michaud, D. 2010. Plant cystatins. Biochimie. 92(11): 1657-1666.

Benkert, P., Schwede, T., and Tosatto, S.C. 2009. QMEANclust: estimation of protein model quality by combining a composite scoring function with structural density information. BMC Struct Biol 9: 35. doi: 
1 Björck, L., Åkesson, P., Bohus, M., Trojnar, J., Abrahamson, M., Olafsson, I., and Grubb, A. 1989. Bacterial 2 growth blocked by a synthetic peptide based on the structure of a human proteinase inhibitor. Nature. $3 \quad 337(6205): 385-386$.

4 Bode, W., Engh, R., Musil, D., Thiele, U., Huber, R., Karshikov, A., Brzin, J., Kos, J., and Turk, V. 1988. The $5 \quad 2.0$ A X-ray crystal structure of chicken egg white cystatin and its possible mode of interaction with cysteine 6 proteinases. EMBO J. 7(8): 2593-2599.

7 Bolter, C.J. 1993. Methyl jasmonate induces papain inhibitor (s) in tomato leaves. PlantPhysiol. 103(4): 134781353.

9 Brown, W.M., and Dziegielewska, K.M. 1997. Friends and relations of the cystatin superfamily--new members 10 and their evolution. Protein Sci 6(1): 5-12. doi: 10.1002/pro.5560060102.

11 Brzin, J.e., Rogelj, B., Popovič, T., Štrukelj, B., and Ritonja, A. 2000. Clitocypin, a new type of cysteine 12 proteinase inhibitor from fruit bodies of mushroom Clitocybe nebularis. J Biol Chem. 275(26): 20104-20109.

13 Chang-jie, X., Kun-song, C., and Ferguson, I.B. 2004. Programmed cell death features in apple suspension cells 14 under low oxygen culture. J Zhejiang Univ Sci. 5(2): 137-143.

Chen, R., Li, L., and Weng, Z. 2003. ZDOCK: An initial-stage protein-docking algorithm. Proteins. 52(1): 8087.

Chu, M.H., Liu, K.L., Wu, H.Y., Yeh, K.W., and Cheng, Y.S. 2011. Crystal structure of tarocystatin-papain complex: implications for the inhibition property of group-2 phytocystatins. Planta 234(2): 243-254. doi: 10.1007/s00425-011-1398-8.

Claeys, H., and Inze, D. 2013. The agony of choice: how plants balance growth and survival under waterlimiting conditions. Plant Physiol 162(4): 1768-1779. doi: 10.1104/pp.113.220921.

Corre-Menguy, F., Cejudo, F.J., Mazubert, C., Vidal, J., Lelandais-Briere, C., Torres, G., Rode, A., and Hartmann, C. 2002. Characterization of the expression of a wheat cystatin gene during caryopsis development. Plant Mol Biol. 50(4-5): 687-698.

Dixon, M., and Webb, E. 1979. Enzyme inhibition and activation. Enzymes. $3^{\text {rd }}$ Edition, Academic Press: New York: 126-136.

27 Dubois, M., Gilles, K.A., Hamilton, J.K., Rebers, P., and Smith, F. 1956. Colorimetric method for determination 28 of sugars and related substances. Anal. Chem. 28(3): 350-356.

29 Ellman, G.L. 1959. Tissue sulfhydryl groups. Arch Biochem Biophys. 82(1): 70-77. 
1 Erickson, H.P. 2009. Size and Shape of Protein Molecules at the Nanometer Level Determined by

2 Sedimentation, Gel Filtration, and Electron Microscopy. Biol Proced Online. 11:32-51. doi:10.1007/s12575-

3 009-9008-x.

4 García Olmedo, F., Salcedo Duran, G., Sánchez-Monge Laguna de Rins, R., Gómez, L., Royo, J., and

5 Carbonero Zalduegui, P. 1987. Plant proteinaceous inhibitors of proteinases and alpha-amylases. Oxf. Surv.

$6 \quad$ Plant Mol. Cell Biol. 4: 275-334.

7 Gill, S.S., Gill, R., Kumar, G., Pareek, A., Sharma, P.C., Anjum, N.A., and Tuteja, N. 2012. Mustard: 8 Approaches for Crop Improvement and Abiotic Stress Tolerance. Improving Crop Resistance to Abiotic Stress,

9 Volume 1 \& Volume 2 (eds N. Tuteja, S. S. Gill, A. F. Tiburcio and R. Tuteja), pp: 1351-1368. Wiley-VCH

10 Verlag GmbH \& Co. KGaA, Weinheim, Germany. doi: 10.1002/9783527632930.ch52

11 Green, A.R., Nissen, M.S., Kumar, G.N., Knowles, N.R., and Kang, C. 2013. Characterization of Solanum 12 tuberosum multicystatin and the significance of core domains. Plant Cell. 25(12): 5043-5052. doi: $13 \quad 10.1105 /$ tpc. 113.121004.

14 Gutierrez-Campos, R., Torres-Acosta, J.A., Saucedo-Arias, L.J., and Gomez-Lim, M.A. 1999. The use of cysteine proteinase inhibitors to engineer resistance against potyviruses in transgenic tobacco plants. Nat Biotechnol. 17(12): 1223-1226.

Haq, S.K., Atif, S.M., and Khan, R.H. 2004. Protein proteinase inhibitor genes in combat against insects, pests, and pathogens: natural and engineered phytoprotection. Arch Biochem Biophys. 431(1): 145-159.

Hong, J.K., Hwang, J.E., Chung, W.S., Lee, K.O., Choi, Y.J., Gal, S.W., Park, B.-S., and Lim, C.O. 2008. Expression of a Chinese cabbage cysteine proteinase inhibitor, BrCYS1, retards seed germination and plant growth in transgenic Tobacco plant. Journal of Plant Biology 51(5): 347-353. cabbage phytocystatin-1. Genes \& Genomics 34(1): 13-18. Irene, D., Chung, T.Y., Chen, B.J., Liu, T.H., Li, F.Y., Tzen, J.T., Wang, C.I., and Chyan, C.L. 2012. Solution structure of a phytocystatin from Ananas comosus and its molecular interaction with papain. PLoS One 7(11): e47865. doi: 10.1371/journal.pone.0047865.

27 Khan, M.S., and Bano, B. 2009. Purification, characterization and kinetics of thiol protease inhibitor from goat (Capra hircus) lung. Biochemistry (Mosc). 74(7): 781-788. 
1 Khan, Y.A., Khan, M.A.H., and Abidi, S. 2014. 2D-PAGE analysis of the soluble proteins of the tropical liver

2 fluke, Fasciola gigantica and biliary amphistome, Gigantocotyle explanatum, concurrently infecting Bubalus

3 bubalis. Journal of Parasitic Diseases: 1-4.

4 Kratsch, H., and Wise, R. 2000. The ultrastructure of chilling stress. Plant Cell Environ. 23(4): 337-350.

5 Kunitz, M. 1947. Crystalline soybean trypsin inhibitor II. General properties. J Gen Physiol. 30(4): 291-310.

6 Kuroda, M., Ishimoto, M., Suzuki, K., Kondo, H., Abe, K., Kitamura, K., and Arai, S. 1996. Oryzacystatins

7 exhibit growth-inhibitory and lethal effects on different species of bean insect pests, Callosobruchus chinensis

8 (Coleoptera) and Riptortus clavatus (Hemiptera). Biosci. Biotech. Biochem. 60(2): 209-212.

9 Laemmli, U.K. 1970. Cleavage of structural proteins during the assembly of the head of bacteriophage T4.

10 Nature 227(5259): 680-685.

11 Lalles, J., Toullec, R., Pardal, P.B., and Sissons, J. 1995. Hydrolyzed soy protein isolate sustains high nutritional

12 performance in veal calves. J Dairy Sci. 78(1): 194-204.

13 Laskowski, R.A., MacArthur, M.W., Moss, D.S., and Thornton, J.M. 1993. PROCHECK: a program to check

14 the stereochemical quality of protein structures. J App Crystallogr. 26(2): 283-291.

Laurent, T.C., and Killander, J. 1964. A theory of gel filtration and its exeperimental verification. J Chromatogr

A. 14: 317-330.

Lim, C.O., Lee, S.I., Chung, W.S., Park, S.H., Hwang, I., and Cho, M.J. 1996. Characterization of a cDNA encoding cysteine proteinase inhibitor from Chinese cabbage (Brassica campestris L. ssp. pekinensis) flower buds. Plant Mol Biol. 30(2): 373-379.

Lowry, O.H., Rosebrough, N.J., Farr, A.L., and Randall, R.J. 1951. Protein measurement with the Folin phenol reagent. J Biol Chem 193(1): 265-275.

Machleidt, W., Thiele, U., Laber, B., Assfalg-Machleidt, I., Esterl, A., Wiegand, G., Kos, J., Turk, V., and

Bode, W. 1989. Mechanism of inhibition of papain by chicken egg white cystatin: Inhibition constants of Nindicate a complex functional relationship. BMC Evol Biol. 8(1): 198. 
1 Martinez, M., Lopez-Solanilla, E., Rodriguez-Palenzuela, P., Carbonero, P., and Diaz, I. 2003. Inhibition of

2 plant-pathogenic fungi by the barley cystatin Hv-CPI (gene Icy) is not associated with its cysteine-proteinase

3 inhibitory properties. Mol Plant Microbe Interact. 16(10): 876-883.

4 Menard, R., Carriere, J., Laflamme, P., Plouffe, C., Khouri, H.E., Vernet, T., Tessier, D.C., Thomas, D.Y., and

5 Storer, A.C. 1991. Contribution of the glutamine 19 side chain to transition-state stabilization in the oxyanion

6 hole of papain. Biochemistry 30(37): 8924-8928.

7 Michaud, D., Nguyen-Quoc, B., and Yelle, S. 1993. Selective inhibition of Colorado potato beetle cathepsin H

8 by oryzacystatins I and II. FEBS Lett. 331(1-2): 173-176.

9 Micsonai, A., Wien, F., Kernya, L., Lee, Y.H., Goto, Y., Refregiers, M., and Kardos, J. 2015. Accurate

10 secondary structure prediction and fold recognition for circular dichroism spectroscopy. Proc Natl Acad Sci U S

11 A 112(24): E3095-3103. doi: 10.1073/pnas.1500851112.

12 Ohtsubo, S., Kobayashi, H., Noro, W., Taniguchi, M., and Saitoh, E. 2005. Molecular cloning and 13 characterization of oryzacystatin-III, a novel member of phytocystatin in rice (Oryza sativa L. japonica). J Agric

14 Food Chem. 53(13), 5218-5224.

15 Ouchterlony, O., and Nilsson, L. 1978. Immunodiffusion and immunoelectrophoresis. Handbook of experimental immunology 1: 32.31-32.50.

Panda, H., 2010. Handbook on Spices and Condiments (Cultivation, Processing and Extraction). Asia Pacific Business Press Inc.:470-473

Pernas, M., Sánchez-Monge, R., Gómez, L., and Salcedo, G. 1998. A chestnut seed cystatin differentially effective against cysteine proteinases from closely related pests. Plant Mol Biol. 38(6): 1235-1242.

Pernas, M., Sánchez-Monge, R., and Salcedo, G. 2000. Biotic and abiotic stress can induce cystatin expression in chestnut. FEBS Lett. 467(2-3): 206-210. Pettersen, E.F., Goddard, T.D., Huang, C.C., Couch, G.S., Greenblatt, D.M., Meng, E.C., and Ferrin, T.E. 2004. UCSF Chimera - a visualization system for exploratory research and analysis. J Comput Chem. 25(13): 16051612.

Priyadarshini, M., and Bano, B. 2010. Cystatin like thiol proteinase inhibitor from pancreas of Capra hircus: purification and detailed biochemical characterization. Amino Acids 38(4): 1001-1010. doi: 10.1007/s00726009-0308-X. seeds. Phytochemistry, 65(1), 19-30. 
1 Rashid, F., Sharma, S., and Bano, B. 2006. Detailed biochemical characterization of human placental cystatin 2 (HPC). Placenta 27(8): 822-831. doi: 10.1016/j.placenta.2005.09.005.

3 Redzynia, I., Ljunggren, A., Bujacz, A., Abrahamson, M., Jaskolski, M., and Bujacz, G. 2009. Crystal structure 4 of the parasite inhibitor chagasin in complex with papain allows identification of structural requirements for 5 broad reactivity and specificity determinants for target proteases. FEBS J. 276(3): 793-806. doi: 10.1111/j.1742$6 \quad 4658.2008 .06824 . x$.

7 Ryan, C.A. 1990. Protease inhibitors in plants: genes for improving defenses against insects and pathogens. 8 Annu Rev Phytopathol. 28(1): 425-449.

9 Šali, A., and Blundell, T.L. 1993. Comparative protein modelling by satisfaction of spatial restraints. J Mol 10 Biol. 234(3): 779-815.

11 Santana, L., Costa, M., Pirovani, N., Almeida, A., Alvim, F., and Pirovani, C. 2014. TcCYS4, a cystatin from 12 cocoa, reduces necrosis triggered by MpNEP2 in tobacco plants. Genet Mol Res. 13(3): 7636-7648.

13 Scott WRP, Hunenberger PH, Tironi IG, Mark AE, Billeter SR, Fennen J, et al. 1999. The GROMOS 14 Biomolecular Simulation Program Package. J Phys Chem A. 103: 3596-3607.

Shabala, S. 2009. Salinity and programmed cell death: unravelling mechanisms for ion specific signalling. J ExpBot. 60(3): 709-712.

Sharma, S., Rashid, F., and Bano, B. 2006. Studies on low molecular mass phytocystatins purified from Phaseolus mungo (Urd). Biochemistry (Mosc). 71(4): 406-413. doi: 10.1134/s0006297906040080.

Shekhawat, K., Rathore, S.S., Premi, O.P., Kandpal, B.K., and Chauhan, J.S. 2012. Advances in Agronomic Management of Indian Mustard (Brassica juncea (L.) Czernj. Cosson): An Overview. Int J Agron. 2012: 1-14. doi: 10.1155/2012/408284.

Shyu, D.J., Chou, W.-M., Yiu, T.-J., Lin, C.P., and Tzen, J.T. 2004. Cloning, functional expression, and characterization of cystatin in sesame seed. J Agric Food Chem. 52(5): 1350-1356. Soding, J., Thompson, J.D., and Higgins, D.G. 2011. Fast, scalable generation of high-quality protein multiple sequence alignments using Clustal Omega. Mol Syst Biol 7: 539. doi: 10.1038/msb.2011.75. $431-443$. 
1 Stubbs, M., Laber, B., Bode, W., Huber, R., Jerala, R., Lenarcic, B., and Turk, V. 1990. The refined 2.4 A X-ray

2 crystal structure of recombinant human stefin B in complex with the cysteine proteinase papain: a novel type of

3 proteinase inhibitor interaction. EMBO J. 9(6): 1939-1947.

4 Sumbul, S., and Bano, B. 2006. Purification and characterization of high molecular mass and low molecular

5 mass cystatin from goat brain. Neurochem Res 31(11): 1327-1336. doi: 10.1007/s11064-006-9175-y.

6 Tian, R.-H., Zhang, G.-Y., Yan, C.-H., and Dai, Y.-R. 2000. Involvement of poly (ADP-ribose) polymerase and

7 activation of caspase-3-like protease in heat shock-induced apoptosis in tobacco suspension cells. FEBS Lett.

8 474(1): 11-15.

9 Turk, B., Turk, V., and Turk, D. 1997. Structural and functional aspects of papain-like cysteine proteinases and 10 their protein inhibitors. Biol Chem. 378(3-4): 141-150.

11 UniProt, C. 2015. UniProt: a hub for protein information. Nucleic Acids Res. 43(Database issue): D204-212. 12 doi: 10.1093/nar/gku989.

13 Voller, A., Bidwell, D., and Bartlett, A. 1976. Enzyme immunoassays in diagnostic medicine: Theory and 14 practice*. Bull World Health Organ. 53(1): 55-65.

15 Walker, A.J., Urwin, P.E., Atkinson, H.J., Brain, P., Glen, D.M., and Shewry, P.R. 1999. Transgenic 16 Arabidopsis leaf tissue expressing a modified oryzacystatin shows resistance to the field slug Deroceras reticulatum (Müller). Transgenic Res. 8(2): 95-103.

Wallner, B., and Elofsson, A. 2003. Can correct protein models be identified? Protein Sci. 12(5): 1073-1086. doi: $10.1110 /$ ps.0236803.

Walsh, T.A., and Strickland, J.A. 1993. Proteolysis of the 85-kilodalton crystalline cysteine proteinase inhibitor from potato releases functional cystatin domains. Plant Physiol. 103(4): 1227-1234. inhibitory mechanism and antifungal activity between group-1 and group-2 phytocystatins from taro (Colocasia esculenta). FEBS J. 275(20): 4980-4989.

Wu, J., and Haard, N.F. 2000. Purification and characterization of a cystatin from the leaves of methyl jasmonate treated tomato plants. Comparative Biochemistry and Physiology Part C: Pharmacology, Toxicology and Endocrinology 127(2): 209-220. protein isolation. Biotechnol Bioeng. 32(1): 100-104. 
1 Zafar, A., Ahmad, S., Rizvi, A., and Ahmad, M. 2015. Novel Non-Peptide Inhibitors against SmCL1 of

2 Schistosoma mansoni: In Silico Elucidation, Implications and Evaluation via Knowledge Based Drug

3 Discovery. PLoS One 10(5): e0123996. doi: 10.1371/journal.pone.0123996.

4 Zhang, X., Lu, G., Long, W., Zou, X., Li, F., and Nishio, T. 2014. Recent progress in drought and salt tolerance

5 studies in Brassica crops. Breed Sci. 64(1): 60-73.

6 Zhao, Y., Botella, M.A., Subramanian, L., Niu, X., Nielsen, S.S., Bressan, R.A., and Hasegawa, P.M. 1996.

7 Two wound-inducible soybean cysteine proteinase inhibitors have greater insect digestive proteinase inhibitory activities than a constitutive homolog. Plant Physiol. 111(4): 1299-1306.

9

10 


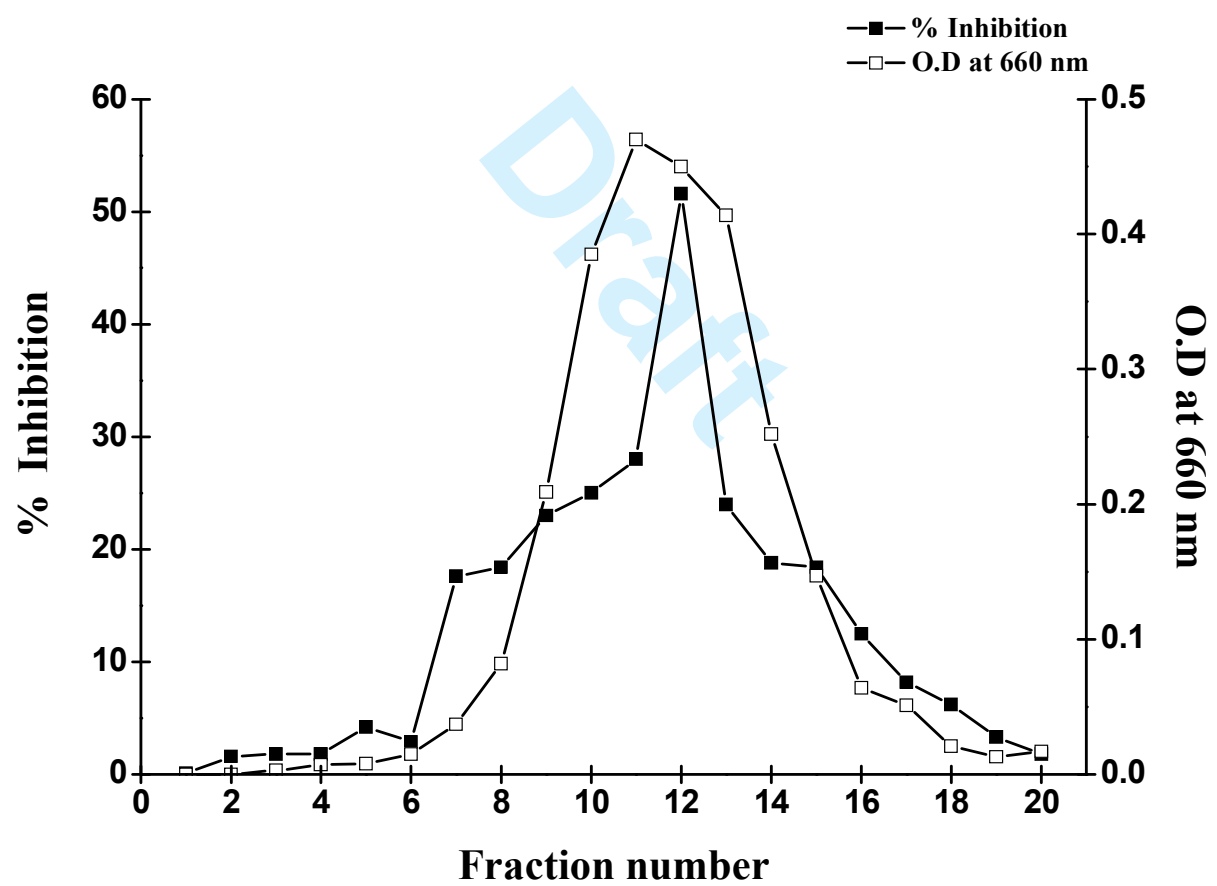

Figure 1. 


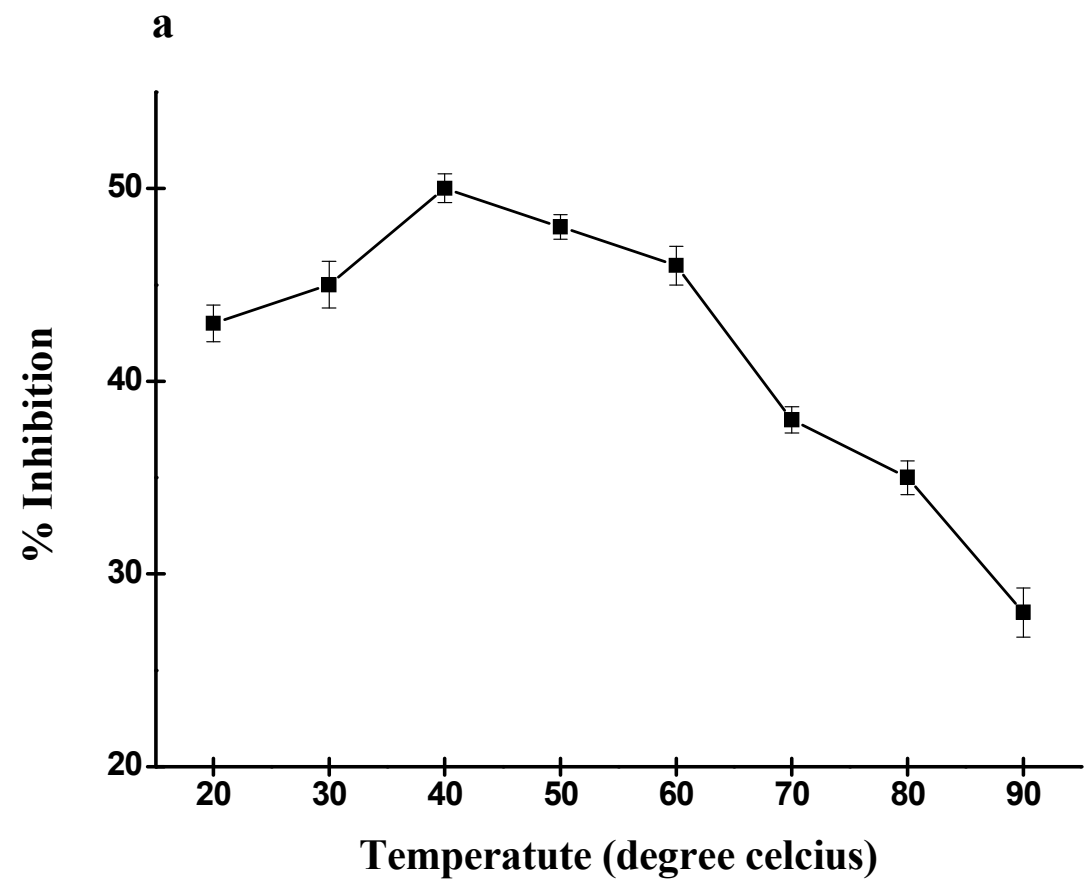

1 2 b

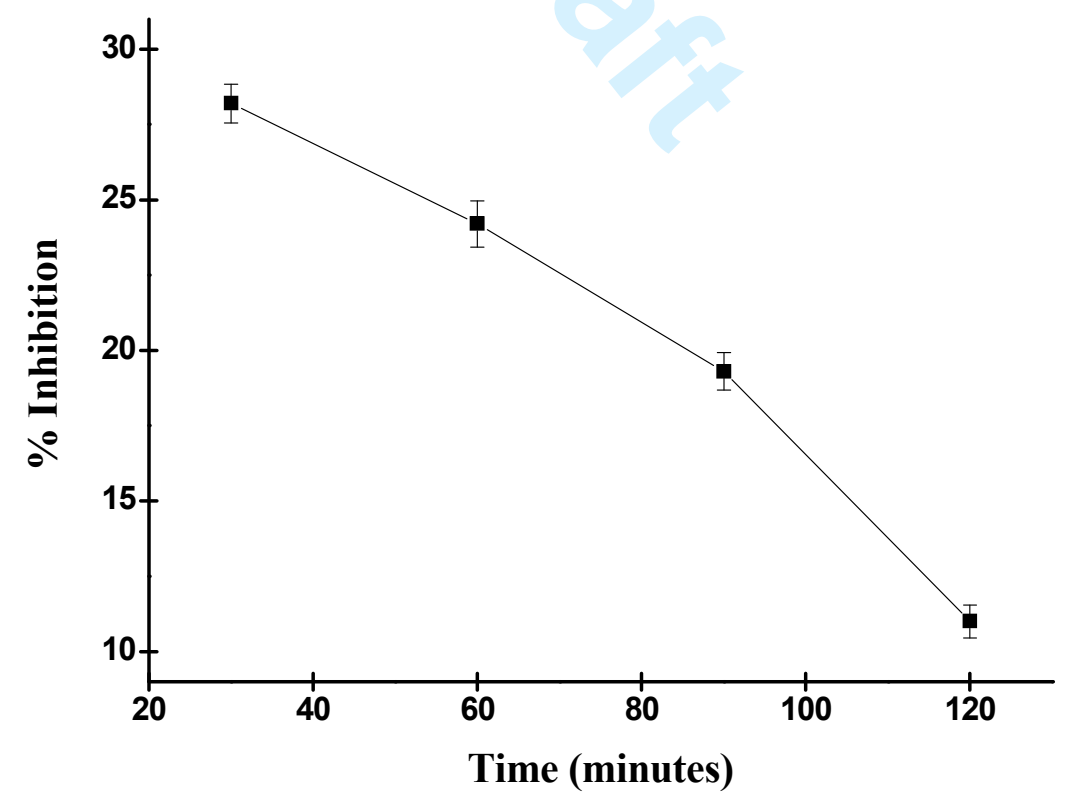

3

Figure 4

5

6 


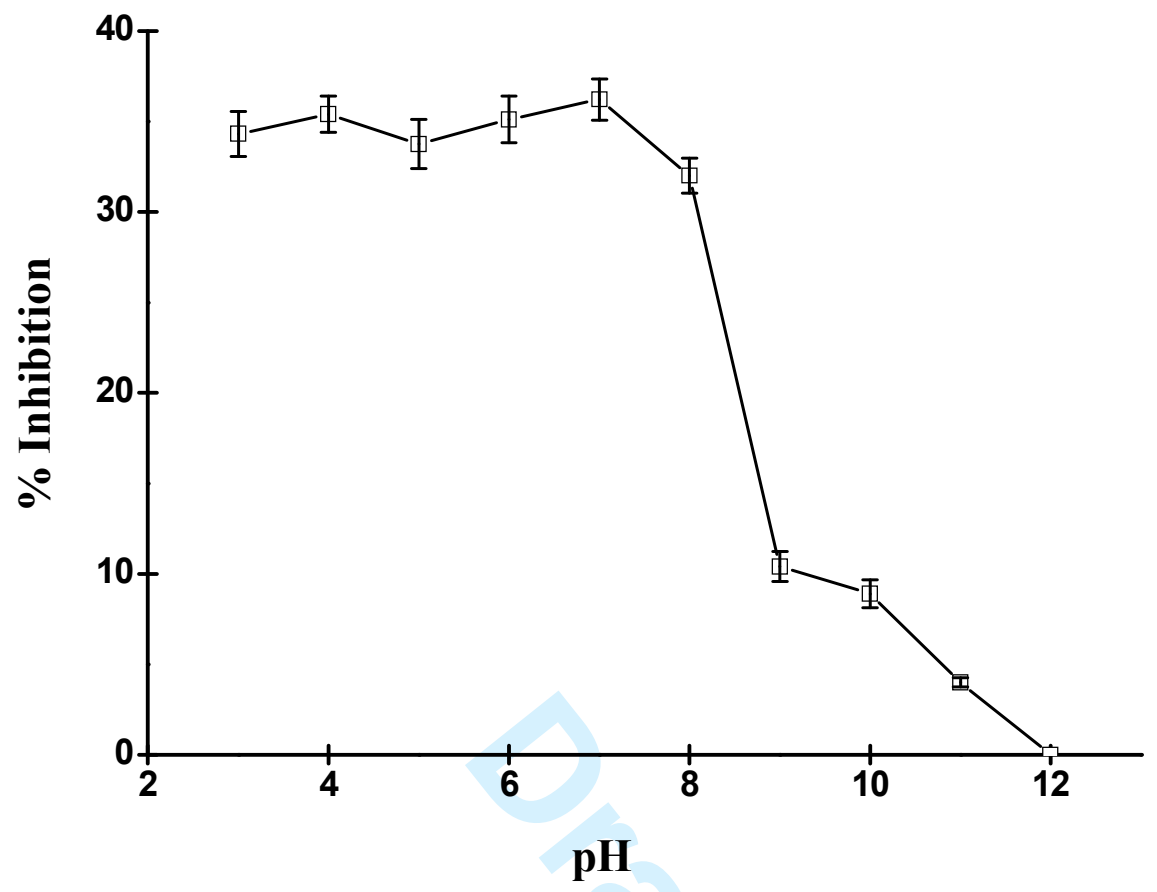

3

4

5

6

7

8

9

10

11

12

13

14

15

16

Figure 5. 


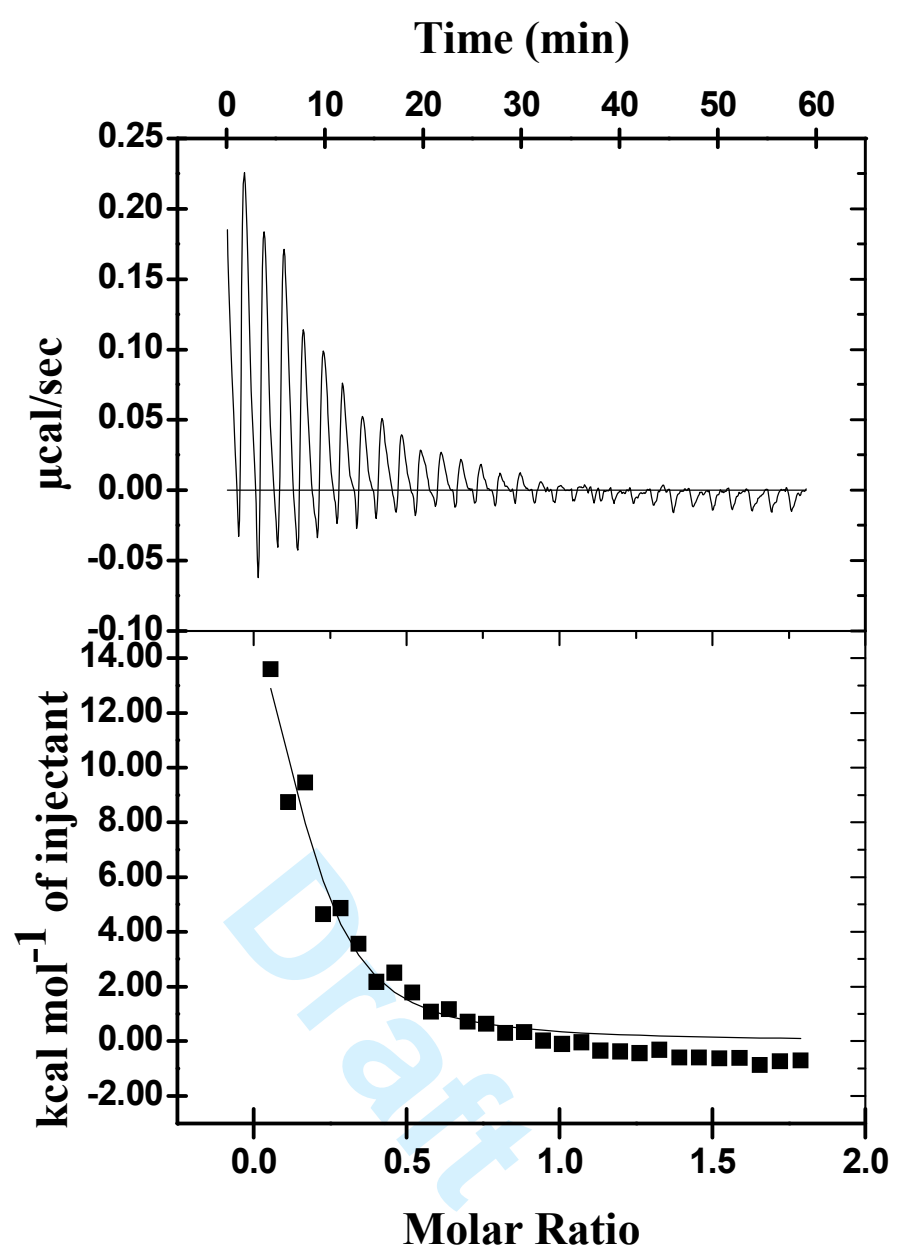




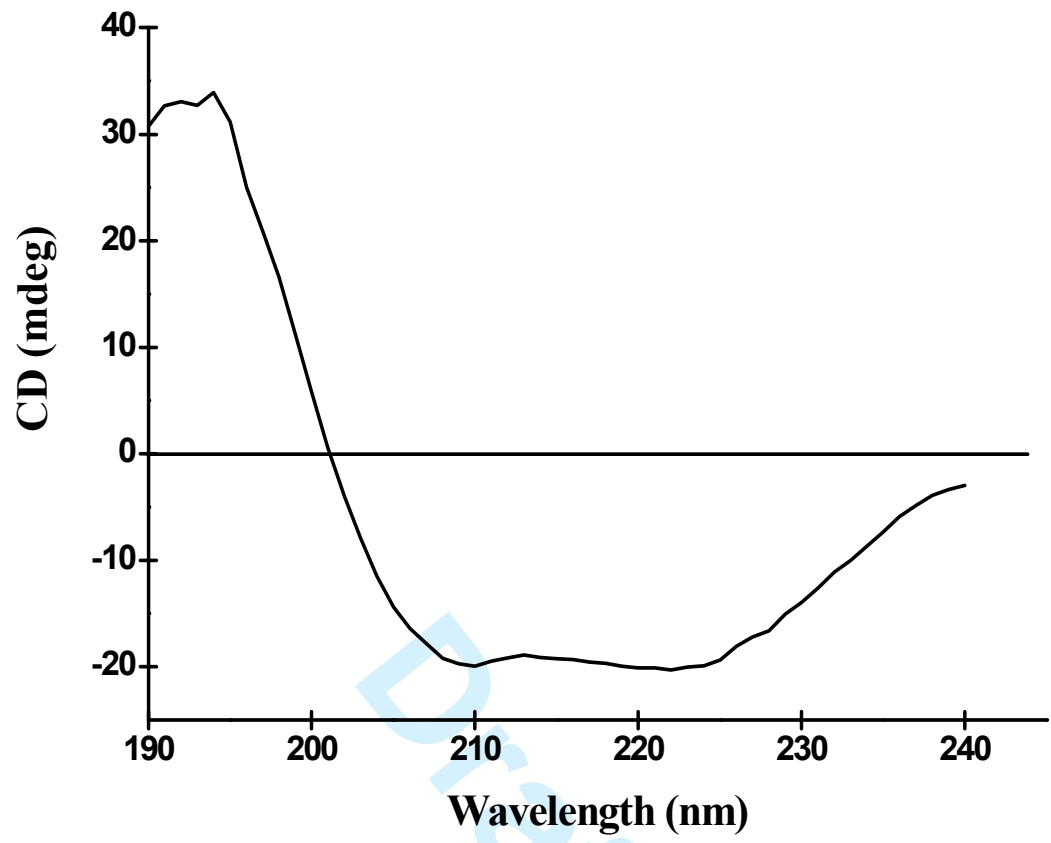

4

6

7

8

9

10

11

12

13

14

15

16

17

Figure 7. 
CLUSTAL O(1.2.1) multiple sequence alignment

$\operatorname{tr} \mid$ Q71QE1 $\mid$ Q71QE1_BRARP
3IMA:D|PDBID|CHAIN|SEQUENCE

tr|Q71QE1|Q71QE1_BRARP 3IMA:D|PDBID|CHAIN |SEQUENCE

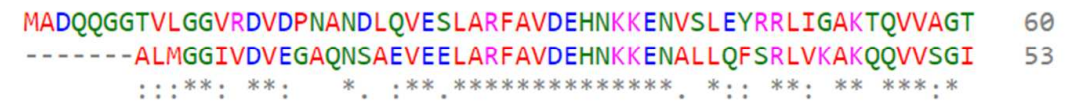

MHHLTVEVADGETKKVYEAKVLEKAWENLKKLEDFTHLRDV 101 MHHLTVEVIEGGKKKVYEAKVWVQAWLNSKKLHEFSPI - - - 91 *********: $: * * * * * * * * \quad: * * * * * * .: *$ : :
7

8

9

10

11

12

13

14

15

16

17

18

19

20

21

22

23

24

\section{Figure 8.}

(1)

11

12

3

4

15

16

17

18

9




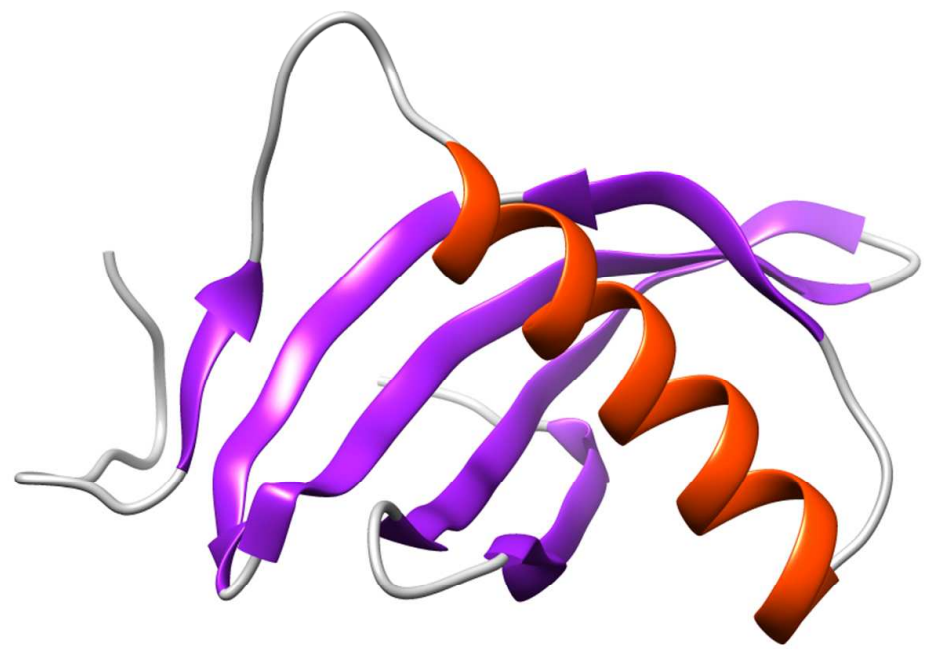

7

8

9

Figure 9. 


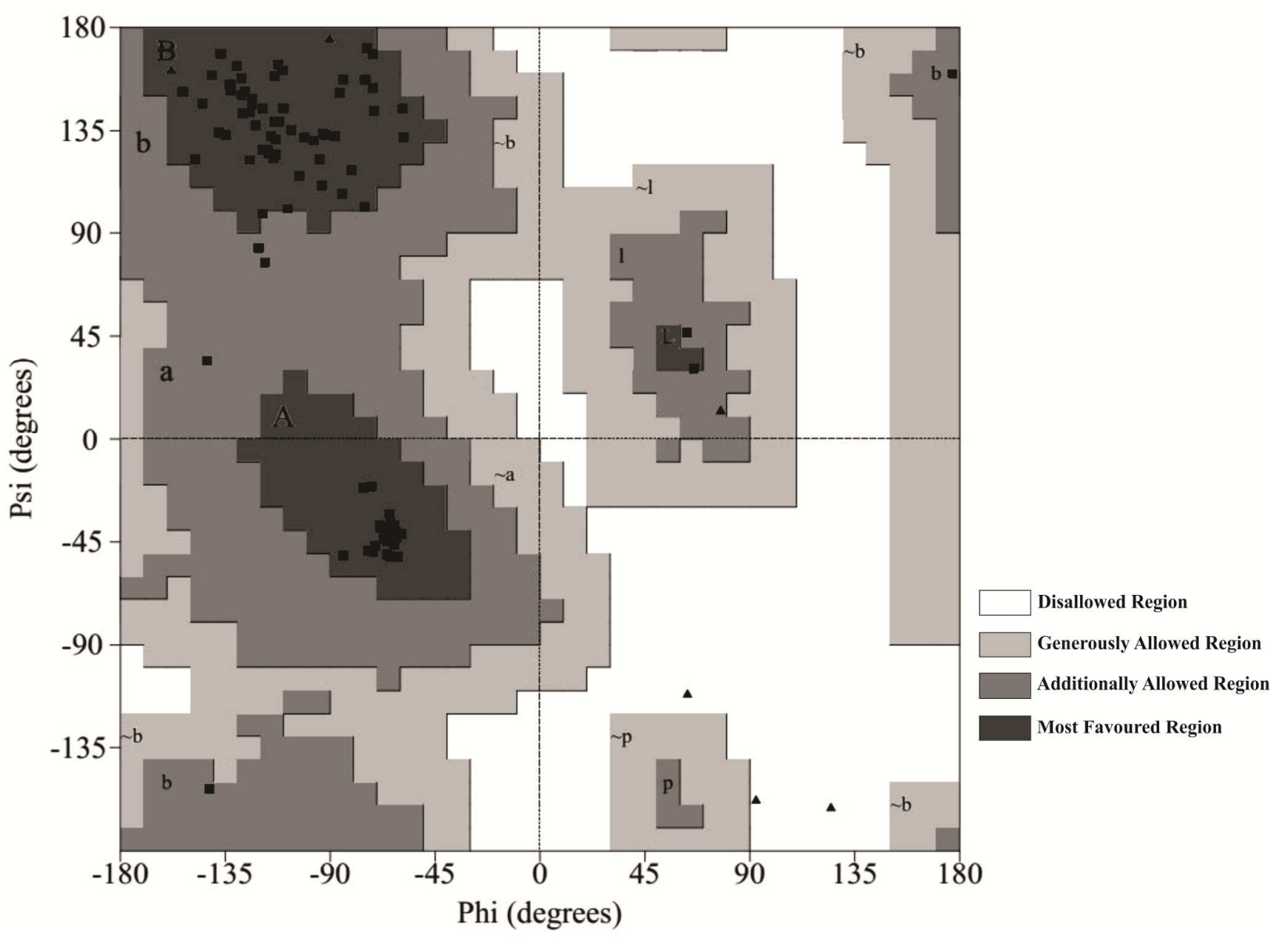


Comparison with non-redundant set of PDB structures

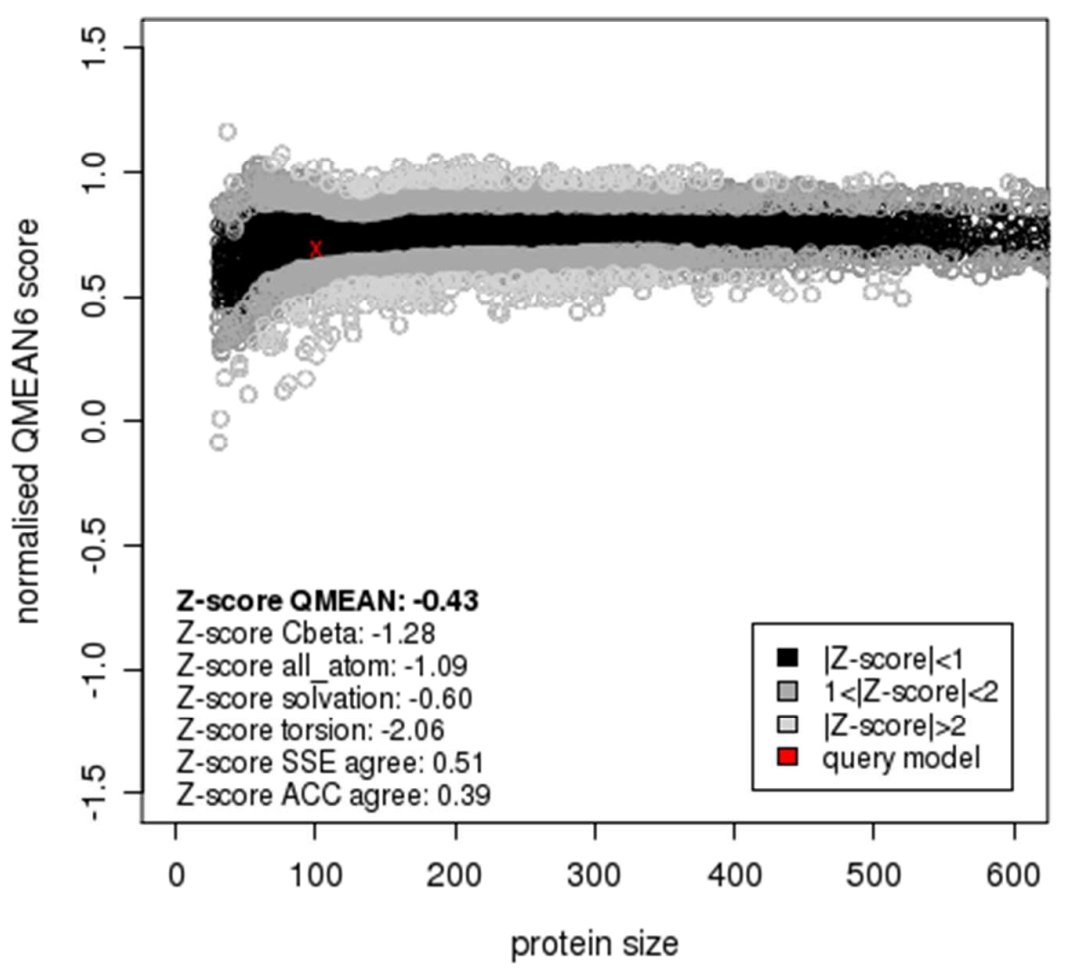

8 


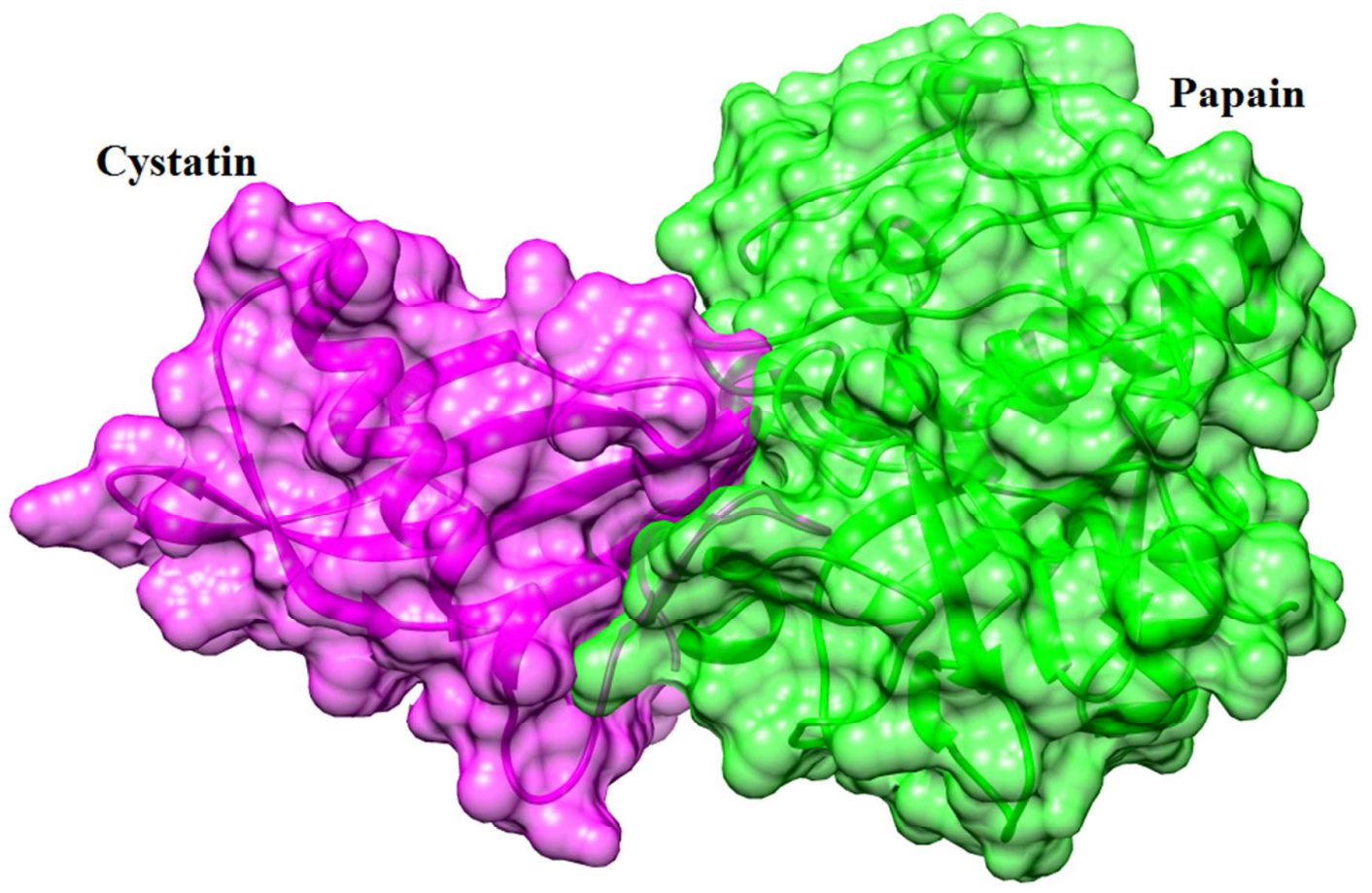

Figure 12. 


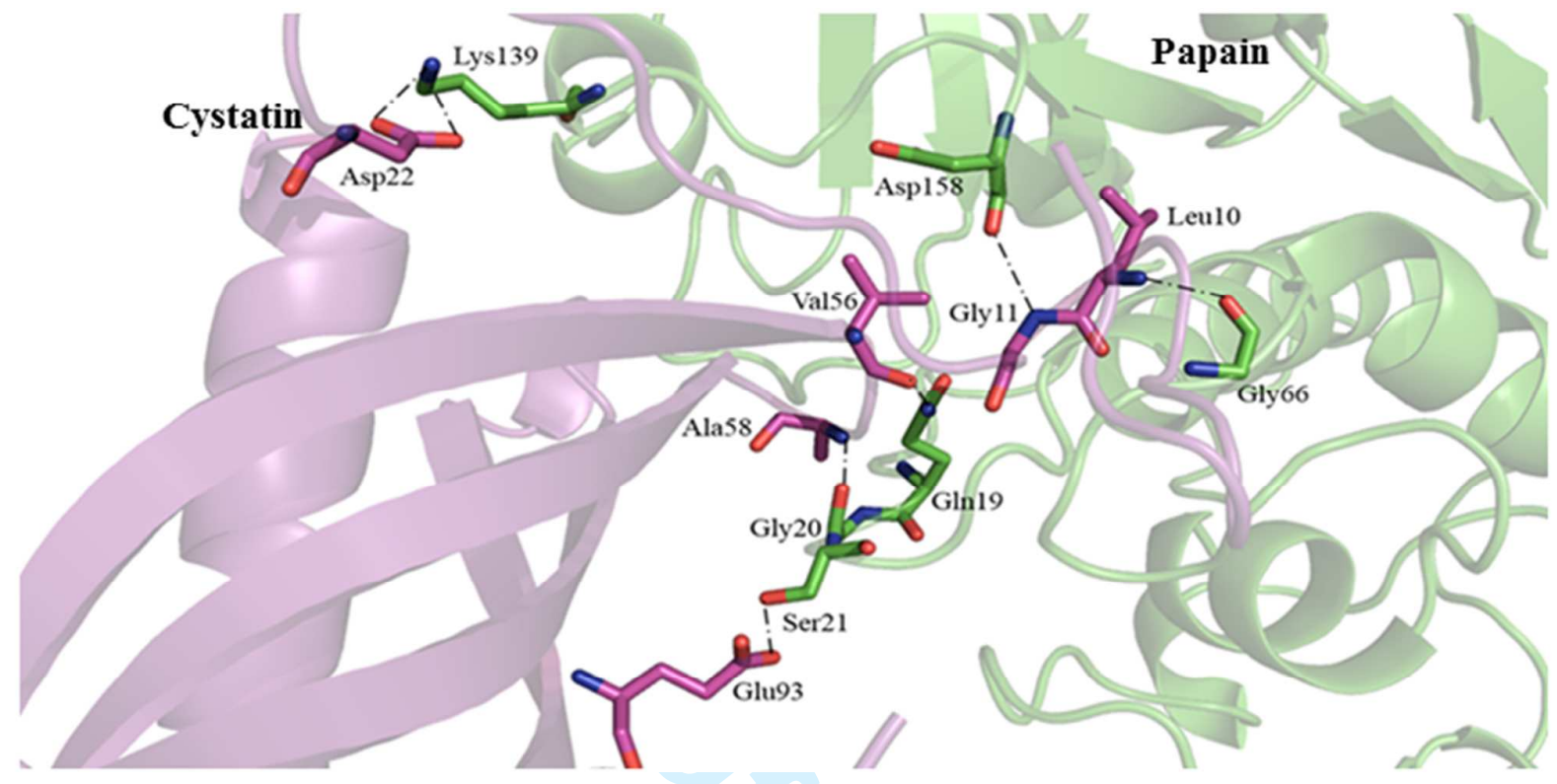

Figure 13.

8 


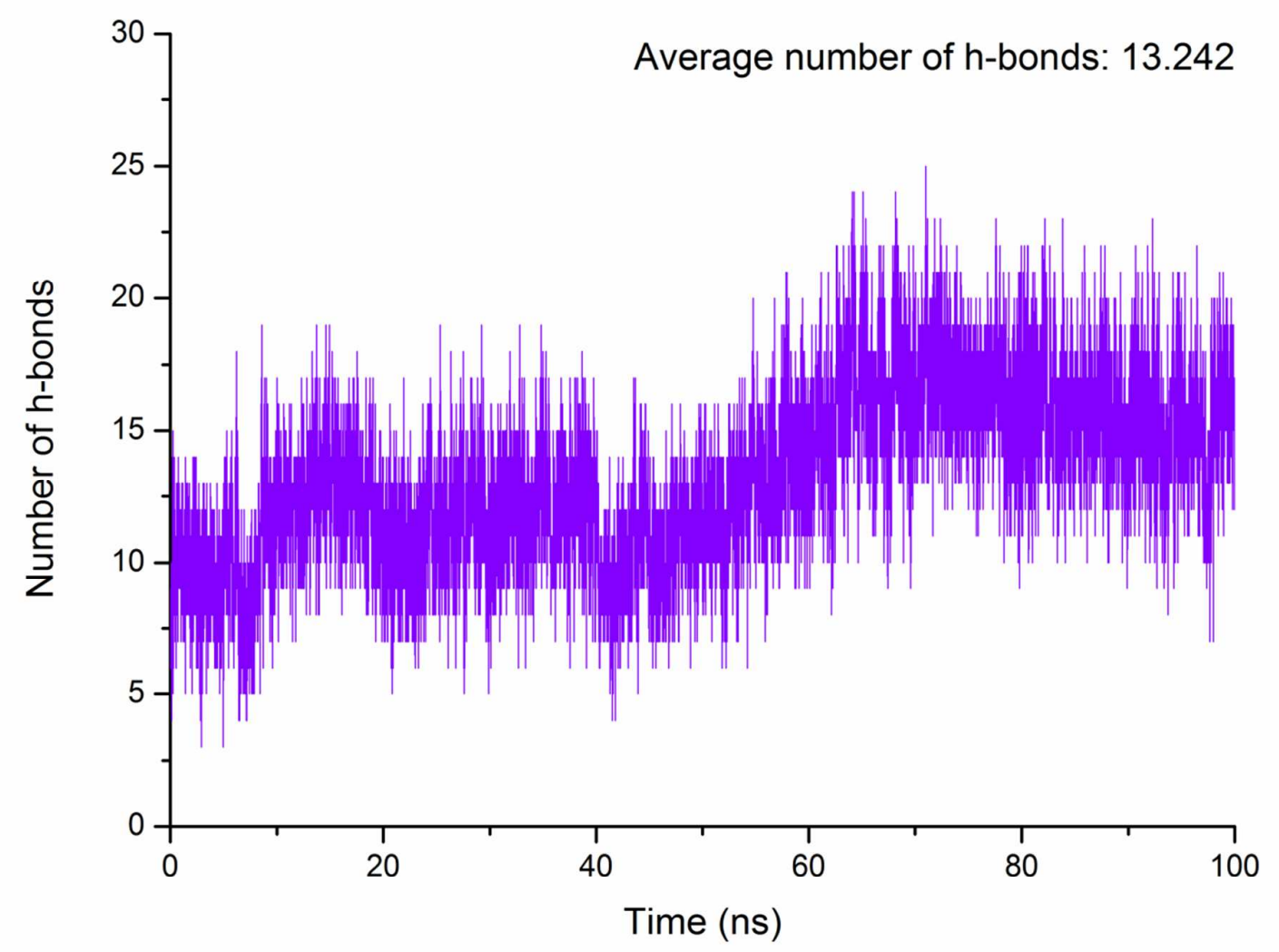

1

3

4

Figure 14

5

6

7

8

9

10

11

12

13

14

15

16

41

https://mc06.manuscriptcentral.com/bcb-pubs 


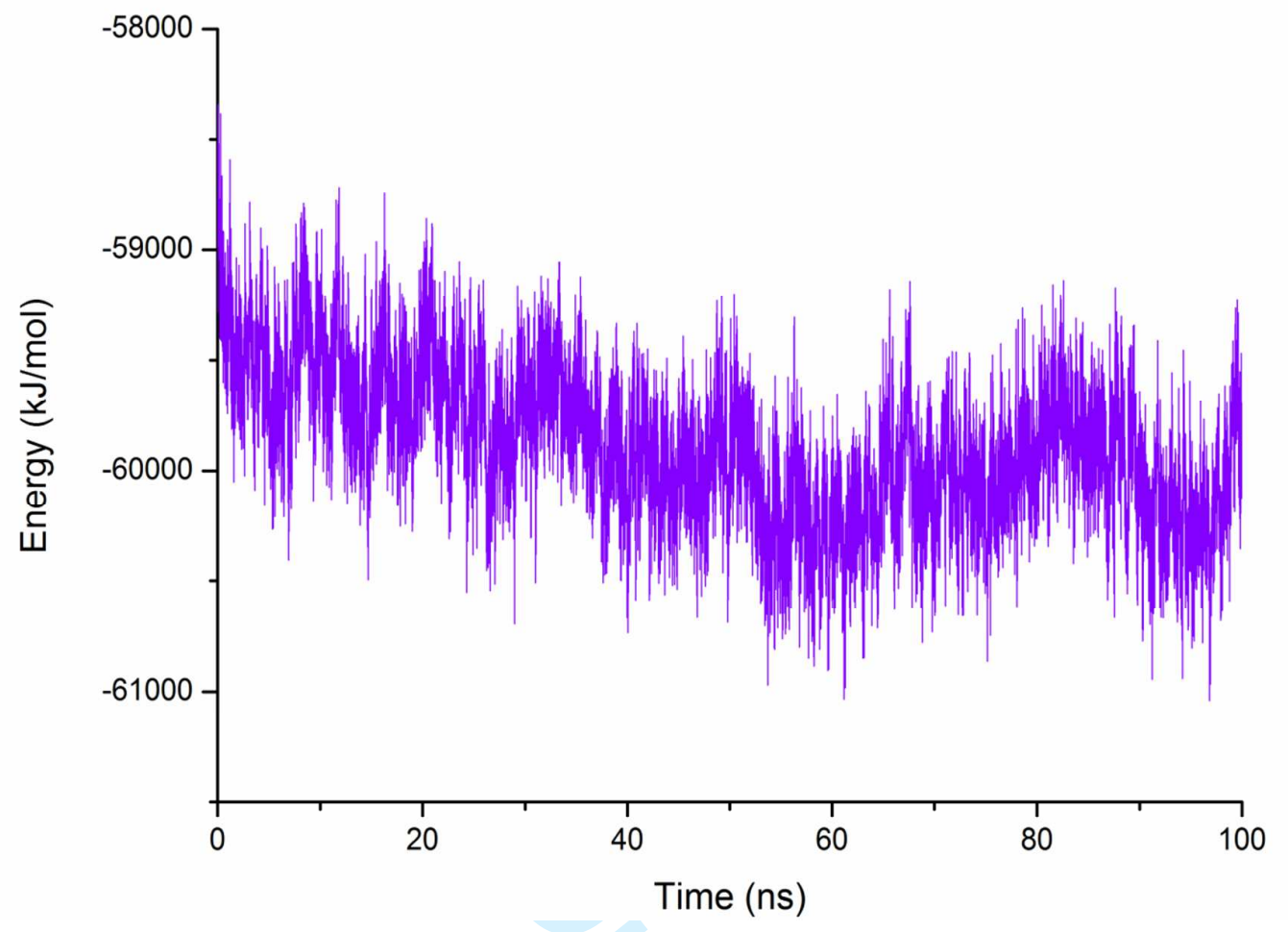

3

4

5

6

7

8

9

10

11

12

13

14

15

16

17

Figure 15

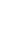

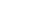

7

8

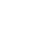

0

1

12 
5 Table 1: Progress of purification of mustard cystatin

\begin{tabular}{lcccccc}
\hline Procedure & $\begin{array}{c}\text { Volume } \\
(\mathbf{m L})\end{array}$ & $\begin{array}{c}\text { Total } \\
\text { Protein } \\
(\mathbf{m g})\end{array}$ & $\begin{array}{c}\text { Total } \\
\text { Units } \dagger\end{array}$ & $\begin{array}{c}\text { Specific } \\
\text { Activity } \\
\text { (Units/mg) }\end{array}$ & $\begin{array}{c}\text { Fold } \\
\text { Purification }\end{array}$ & $\%$ Yield \\
\hline $\begin{array}{l}\text { Crude } \\
\text { homogenate }\end{array}$ & 300 & 6600 & 201 & 0.030 & 1 & 100 \\
$\begin{array}{l}\text { 40-60\% } \\
\text { ammonium } \\
\text { sulphate } \\
\text { precipitation }\end{array}$ & 20 & 452 & 70 & 0.15 & 5 & 34 \\
$\begin{array}{l}\text { Gel filtration } \\
\text { S-100 }\end{array}$ & 10 & 8 & 49 & 6.125 & 204 & 24.3 \\
\hline
\end{tabular}

6

$\dagger 1$ unit of enzyme inhibitory activity is defined as the amount of inhibitor bringing about 0.001 change in OD

$7 \mathrm{ml}^{-1} \mathrm{~min}^{-1}$ under the described assay conditions

\section{8}

9

10

11

12

13

14

15 
7 Table 2. Kinetic constants obtained upon interaction of mustard cystatin with

8 papain,ficin and bromelain

\begin{tabular}{lllll}
\hline Proteinase & $K_{i}(\mu M)$ & $K_{+1}\left(M^{-1} s^{-1}\right)$ & $K_{-1}\left(s^{1}\right)$ & $\begin{array}{l}\text { Half-life of } \\
\text { complex }(s)\end{array}$ \\
\hline Papain & $0.102 \pm 0.005$ & $6.47 \pm 0.2 \times 10^{3}$ & $6.6 \pm 0.25 \times 10^{-4}$ & $1.05 \times 10^{3}$ \\
Ficin & $0.306 \pm 0.003$ & $3.01 \pm 0.1 \times 10^{3}$ & $9.23 \pm 0.1 \times 10^{-4}$ & $7.5 \times 10^{2}$
\end{tabular}

\section{Bromelain \\ $0.468 \pm 0.003$ \\ $2.19 \pm 0.5 \times 10^{3}$ \\ $10.25 \pm 0.2 \times 10^{-4}$ \\ $6.7 \times 10^{2}$}


Table 3.Validation scores from PROCHECK, Qmean and ProQ for top ten theoretical models

5

6

\begin{tabular}{|c|c|c|c|c|c|c|c|}
\hline \multirow[t]{2}{*}{ Model } & \multicolumn{4}{|c|}{ PROCHECK* } & \multirow{2}{*}{$\begin{array}{c}\text { Qmean } \\
\text { (Z-score) }\end{array}$} & \multirow{2}{*}{$\begin{array}{c}\text { ProQ } \\
\text { (LGscore) }\end{array}$} & \multirow{2}{*}{$\begin{array}{c}\text { ProQ } \\
(\text { MaxSub) }\end{array}$} \\
\hline & $A$ & $b$ & $c$ & $\bar{d}$ & & & \\
\hline Model_07 & 92.3 & 7.7 & $\mathbf{0}$ & $\mathbf{0}$ & -0.43 & 2.096 & 0.307 \\
\hline Model_13 & 90.1 & 8.8 & 0 & 1.1 & -0.3 & 1.485 & 0.275 \\
\hline Model_32 & 86.8 & 12.1 & 1.1 & 0 & -0.68 & 1.81 & 0.292 \\
\hline Model_34 & 91.2 & 8.8 & 0 & 0 & -1.61 & 1.527 & 0.252 \\
\hline Model_35 & 85.7 & 14.3 & 0 & 0 & -1.03 & 1.415 & 0.248 \\
\hline Model_40 & 93.4 & 6.6 & 0 & 0 & -1.41 & 1.915 & 0.306 \\
\hline Model_47 & 87.9 & 12.1 & 0 & 0 & -1.12 & 1.418 & 0.261 \\
\hline Model_83 & 90.1 & 9.9 & 0 & 0 & -1.04 & 1.53 & 0.282 \\
\hline Model_86 & 91.2 & 7.7 & 1.1 & 0 & -1.61 & 1.559 & 0.26 \\
\hline Model_89 & 89 & 8.8 & 1.1 & 1.1 & -1.03 & 1.465 & 0.265 \\
\hline
\end{tabular}

*a, b, c, d, values correspond to the percentages of residues that are located in the most favourable, additionally 8 allowed, generously allowed and disallowed regions, respectively 
1

2

3

4

5

6

7

8

9

\begin{tabular}{ccc}
\hline Papain & Phytocystatin & Bond length $(\AA)$ \\
\hline Asp158 & Gly11 & $\mathbf{3 . 2 1}$ \\
Gln19 & Val56 & $\mathbf{3 . 4 1}$ \\
Gly20 & Ala58 & 2.05 \\
Ser21 & Glu93 & 3.48 \\
Gly66 & Leu10 & 3.17 \\
Lys139 & Asp22 & 2.63 \\
Lys139 & Asp22 & 2.79 \\
\hline
\end{tabular}

10

11

12

13

14

15

16

17

18

19

20

21

22

23

24

Table 4. Summary of hydrogen bond interactions between papain and modelled phytocystatin.

1

3

4

5

19

21

22

23

46

https://mc06.manuscriptcentral.com/bcb-pubs 
Table 5. Residue pairs involved in hydrogen bonding at various intervals during the simulation.

\begin{tabular}{|c|c|c|}
\hline $\begin{array}{l}\text { Time } \\
\text { Period }\end{array}$ & $\begin{array}{l}\text { H- } \\
\text { bonds }\end{array}$ & Papain and Cystatin complex: pair residues involved" \\
\hline $20 \mathrm{~ns}$ & 14 & $\begin{array}{l}\text { Gly20-Ala58, Gly62-Asp3, Cys63-Gln4, Cys63-Gln55, Asn64-Gly11, Gln92-Asp3, } \\
\text { Gln92-Gln4, Gln142-Glu83, Gln142-Lys84, Arg145-Ala85, Arg145-Asn88, Lys156- } \\
\text { Arg14, Lys156-Arg14, Asp158-Gly11 }\end{array}$ \\
\hline $40 \mathrm{~ns}$ & 16 & $\begin{array}{l}\text { Gly20-Ala58, Asn64-Gln4, Asn64-Gln5, Asn64-Gly6, Asn64-Gly11, Asn64-Val56, } \\
\text { Gln92-Gln4, Gln142-Thr60, Gln142-Glu83, Gln142-Ala85, Arg145-Trp86, Arg145- } \\
\text { Trp86, Lys156-Arg14, Lys156-Arg14, Asp158-Gly11, Trp177-Val57 }\end{array}$ \\
\hline $60 \mathrm{~ns}$ & 11 & $\begin{array}{l}\text { Gly20-Ala58, Asn64-Gln4, Asn64-Gly6, Asn64-Gly11, Asn64-Val56, Gln92-Gln4, } \\
\text { Gln142-Thr60, Gln142-Glu83, Gln142-Ala85, Asp158-Gly11, Asp158-Arg14 }\end{array}$ \\
\hline $80 \mathrm{~ns}$ & 18 & $\begin{array}{l}\text { Gln19-Val56, Ser21-Met1, Ser21-Ala2, Cys25-Gly11, Cys25-Val56, Cys63-Ala2, Cys63- } \\
\text { Gln4, Asn64-Gly6, Asn64-Gly11, Asn64-Gln55, Asn64-Val56, Gln142-Ala58, Gln142- } \\
\text { Glu83, Lys156-Arg14, Lys156-Asp15, Asp158-Gly11, Asp158-Arg14, Trp177-Val57 }\end{array}$ \\
\hline $100 \mathrm{~ns}$ & 17 & $\begin{array}{l}\text { Gln19-Val57, Gln19-Ala58, Asn64-Gln4, Asn64-Gly6, Asn64-Gly11, Asn64-Gly12, } \\
\text { Asn64-Gln55, Asn64-Val56, Gln92-Gln4, Gln142-Glu83, Gln142-Lys84, Gln142-Trp86, } \\
\text { Lys156-Arg14, Asp158-Gly11, Asp158-Arg14, Asp158-Arg14, Trp177-Val57 }\end{array}$ \\
\hline
\end{tabular}

9 *from the residue pairs, the first belongs to papain and second belongs to cystatin model. 


\section{Figure captions}

2 Figure 1. Purification profile of a mustard cystatin. The crude extract was subjected to ammonium sulphate

3

4

5

6 fractionation followed by Sephacryl S-100 HR gel filtration chromatography. The fractions collected were assayed for inhibitory activity and protein concentration (O.D at 660nm).

Figure 2. 2D gel electrophoresis of the purified mustard cystatin. $200 \mu \mathrm{g}$ of the purified mustard cystatin was focussed on an IPG strip and then subjected to SDS-PAGE on a $12.5 \%$ gel preparation. A single spot observed on the gel suggested the purity of the sample.

Figure 3. Molecular weight determination of cystatin by SDS-PAGE electrophoresis. Lane a contained the molecular mass standards: A- phosphorylase b $(97.4 \mathrm{kDa})$, B- bovine serum albumin $(68 \mathrm{kDa}), \mathrm{C}-$ ovalbumin (45 kDa), D- carbonic anhydrase (29.1 kDa), E- soyabean trypsin inhibitor (20 kDa), F- lysozyme (14.3 kDa). Lane $\mathrm{b}$ contained $60 \mu \mathrm{g}$ of the purified inhibitor and lane $\mathrm{c}$ contained $60 \mu \mathrm{g}$ of 2-mercaptoethanol treated purified inhibitor.

Figure 4. Effect of temperature on the purified TPI:(a) $50 \mu \mathrm{g}$ of the inhibitor was incubated in $50 \mathrm{mM}$ sodium phosphate buffer, $\mathrm{pH} 7.5$, at various temperatures for $30 \mathrm{~min}$. Remaining \% inhibitory activity was analyzed against $50 \mu \mathrm{g}$ of papain at $37^{\circ} \mathrm{C}$. (b) The purified B.juncea cystatin, when incubated at $90^{\circ} \mathrm{C}$ for varying time intervals, retained its anti-papain activity up to 90 minutes. The results are the average of three independent experiments.

Figure 5.pH stability profile of purified TPI. 50 $\mu \mathrm{g}$ of the inhibitor was incubated in buffers in the pH range of 3-12 for 30 mins. Remaining $\%$ inhibitory activity was analysed against $50 \mu \mathrm{g}$ of papain at $37^{\circ} \mathrm{C}$. The results are the average of three independent experiments.

Figure 6. Stoichiometry of papain binding by ITC. The heat released on injecting papain at regular intervals into the mustard cystatin was monitored to study the energetics of binding.

Figure 7.Far UV CD spectrum of the purified inhibitor. Mustard cystatin at a concentration of $0.2 \mathrm{mg} / \mathrm{mL}$ was subjected to $\mathrm{CD}$ spectroscopy. The fractional percentages of secondary structural elements were then calculated. The spectrum is the average of multiple runs.

Figure 8.Multiple sequence alignment to identify the conserved residues. The sequences of phytocystatins and considered template(PDB: 3IMA) were aligned were aligned using clustal omega. The conserved residues are marked with *.

Figure 9.Modelled Brassica phytocystatin. The secondary structure of the modelled phytocystatin was found to be composed of one $\alpha$ helix and six $\beta$ sheets. 
1 Figure 10.Ramachandran plot of the homology modelled structure of phytocystatin. The most favoured,

2 additionally allowed, generously allowed and disallowed regions respectively are defined in the figure.

3 Figure 11.Model validation through QMean Z-score. Absolute quality of modelled structure as evaluated.

4 Good models are generally located in the dark (black) region.

5 Figure 12.Binding mode of phytocystatin with papain. Surface view of the docked complex- Brassica phytocystatin (magenta) and papain (green).

7 Figure 13.Papain-inhibitor interaction. Comprehensive details of the interaction between the Brassica phytocystatins (magenta) and papain (green). Black dashes represent hydrogen bonds.

9 Figure 14. Analysis of protein-protein interaction through hydrogen bonds. Hydrogen bonding pattern as a 10 function of time reveals increased stability of the protein-protein complex with passage of time.

11 Figure 15. Energy pattern for protein-protein interaction. The pattern of energy corresponds to the hydrogen 12 bond formation. Decline in energy on the time scale suggests the strong binding between the proteins. 